\title{
Review Article \\ Mechanisms of Metal Resistance and Homeostasis in Haloarchaea
}

\begin{abstract}
Pallavee Srivastava and Meenal Kowshik
Department of Biological Sciences, Birla Institute of Technology and Science, Pilani, K K Birla Goa Campus, NH-17B, Zuarinagar, Goa 403 726, India
\end{abstract}

Correspondence should be addressed to Meenal Kowshik; meenal@goa.bits-pilani.ac.in

Received 26 October 2012; Revised 20 December 2012; Accepted 10 January 2013

Academic Editor: Elisabetta Bini

Copyright (C) 2013 P. Srivastava and M. Kowshik. This is an open access article distributed under the Creative Commons Attribution License, which permits unrestricted use, distribution, and reproduction in any medium, provided the original work is properly cited.

\begin{abstract}
Haloarchaea are the predominant microflora of hypersaline econiches such as solar salterns, soda lakes, and estuaries where the salinity ranges from 35 to 400 ppt. Econiches like estuaries and solar crystallizer ponds may contain high concentrations of metals since they serve as ecological sinks for metal pollution and also as effective traps for river borne metals. The availability of metals in these econiches is determined by the type of metal complexes formed and the solubility of the metal species at such high salinity. Haloarchaea have developed specialized mechanisms for the uptake of metals required for various key physiological processes and are not readily available at high salinity, beside evolving resistance mechanisms for metals with high solubility. The present paper seeks to give an overview of the main molecular mechanisms involved in metal tolerance in haloarchaea and focuses on factors such as salinity and metal speciation that affect the bioavailability of metals to haloarchaea. Global transcriptomic analysis during metal stress in these organisms will help in determining the various factors differentially regulated and essential for metal physiology.
\end{abstract}

\section{Introduction}

Many metal ions have a key role in the physiology of cells. Metals such as calcium, cobalt, chromium, copper, iron, potassium, magnesium, manganese, sodium, nickel, and zinc are essential and serve as micronutrients. These metals act as the redox centers for metalloproteins such as cytochromes, blue copper proteins, and iron-sulfur proteins which play a vital role in electron transport [1]. As the transition metals exist in numerous oxidation states, they efficiently act as electron carriers during redox reactions of electron transport chains to generate chemical energy $[2,3]$. Metal ions also function as cofactors and confer catalytic potential and stability to proteins [4]. Other metals like silver, mercury, lead, aluminum, cadmium, gold, and arsenic have no biological roles and are potentially toxic to microbes [5]. The toxicity is exerted by the displacement of essential metals from native binding sites or through ligand interactions [6]. Both essential and nonessential metals at high concentrations disrupt cell membrane, alter enzymatic specificity, hinder cellular functions, and damage DNA [5].
Thus, as any disturbance in metal ion homeostasis could produce toxic effects on cell viability, the concentrations of metals within cells are stringently controlled. An increase in the ambient metal concentration leads to activation of metal resistance mechanisms to overcome metal stress. Metal homeostasis has been well studied in bacteria and eukaryotes and is attributed to differential regulation of transporters like $\mathrm{P}_{1 \mathrm{~B}}$-type ATPases, $\mathrm{ABC}$ transporters, cation diffusion facilitators $(\mathrm{CDFs})$, and metallochaperones in response to metals [7-9]. Among the Archaea, thermophiles and hyperthermophiles of the Crenarchaeota and the methanogens and thermophiles of Euryarchaeota utilize $\mathrm{P}_{1 \mathrm{~B}}$-type ATPases and $\mathrm{ABC}$ transporters for metal transport and homeostasis $[10,11]$. However, metal homeostasis in haloarchaea from the phylum Euryarchaeota has not been extensively studied [11].

Haloarchaea are members of the third domain of life, the Archaea, within which a total of 36 genera and 129 species have been identified to date [12]. These organisms require between $10 \%$ and $35 \%$ salt for optimum growth and are the predominant microflora of hypersaline environments such as solar salterns, salt lakes, soda lakes, salt deposits, and so 
forth [13]. However, some low salt tolerant haloarchaea can be found in estuarine environments [14]. Estuaries serve as interfacial mixing zones between rivers and seawaters which determine the flux of chemical species into the ocean [15]. Econiches like estuaries [16] and solar crystallizer ponds [17] may contain high concentrations of metals, since they serve as ecological sinks for metals and as effective traps for river borne metals [18]. Anthropogenic activities like urbanization and industrialization, including mining, agriculture, and waste disposal, further contribute towards metal pollution at these sites $[19,20]$. Haloarchaea have developed various mechanisms of resistance in order to thrive under metal stress [21-23]. However, studies on metal resistance in haloarchaea are still in their infancy.

Most of the reports until now are limited to MIC (minimum inhibitory concentration) studies [24-26]. However, in a study on comparative gene analysis of the role of $\mathrm{P}_{1 \mathrm{~B}^{-}}$ type ATPases in maintaining metal homeostasis in bacteria and archaea, Coombs and Barkay (2005) [10] have shown that $\mathrm{P}_{1 \mathrm{~B}}$-type ATPases containing $\mathrm{N}$-terminal metal-binding motifs are distributed across bacteria and archaea, including haloarchaea. These ATPases along with the ABC transporters, transcriptional regulators, and certain metallochaperones were found to be involved in metal resistance and homeostasis in the haloarchaeon Halobacterium sp. strain NRC-1 [22]. Haloarchaea exhibit a high degree of variation in the concentration of metals that they can tolerate [22, 24-26]. Interestingly, at low concentrations, certain metal ions like $\mathrm{Mn}(\mathrm{II}), \mathrm{Fe}(\mathrm{II}), \mathrm{Co}(\mathrm{II}), \mathrm{Ni}(\mathrm{II})$, and $\mathrm{Zn}$ (II) were found to enhance growth $[22,24]$. An in-depth study at molecular level may help in better understanding of this variation. This paper seeks to give an overview of the main molecular mechanisms involved in metal tolerance in haloarchaea and to outline the factors such as salinity and metal speciation that affect the bio-availability of the metals to haloarchaea. The need for further studies on metal homeostasis and resistance in haloarchaea is highlighted. The elucidation of complete pathways of metal resistance from uptake to transformation/detoxification and efflux will help to determine the final fate of metals. The final metal species could be either volatile or chelated intracellularly and thereby rendered nontoxic to the organism.

\section{Bioavailability of Metals to Haloarchaea}

For a metal to act either as a micronutrient or as a toxicant, it has to be available for uptake by the organism [27]. The metal species determines the solubility, bio-availability, and membrane transport, besides influencing the phenomenon of adsorption, oxidation/reduction, and oceanic residence times [28]. Metal speciation is governed by alkalinity, $\mathrm{pH}$, hardness (presence of $\mathrm{Ca} / \mathrm{Mg}$ ), natural dissolved organic matter, redox potential, and salinity [29]. Strongly complexed and thus nonlabile and particulate metal species are less available to organisms for uptake [30]. As haloarchaea inhabit hypersaline environments with salinity in the range of $2 \%-35 \%$, salinity is proposed to be the most important factor affecting bio-availability. The salt content in hypersaline econiches of solar salterns is about 10 -fold of its concentration in seawater [31] due to evaporation. This process also concentrates other anions and cations present in the sea water including the metal salts fed through contaminated estuaries [32]. The high chloride ion $\left(\mathrm{Cl}^{-}\right)$content in these environments results in the formation of metal chlorocomplexes.

The type of complex formed depends upon the chelating ligand, that is, organic or inorganic ligands, and the kind of heavy metal present in the system [33]. Metals like $\mathrm{Zn}$ and $\mathrm{Cu}$ that have small ionic radii preferentially complex with hard donors containing oxygen like $\mathrm{OH}^{-}, \mathrm{CO}_{2}{ }^{3-}, \mathrm{HCO}_{3}{ }^{-}$, and $\mathrm{SO}_{4}{ }^{2-}$ to form inorganic complexes [34]. Soft acceptors like $\mathrm{Hg}, \mathrm{Cd}$, and $\mathrm{Ag}$ are easily ionized and are thus, more likely to form chlorocomplexes. Although inorganic species exist in natural waters, organic metal species predominate [35]. The complexation of metals with organic ligands reduces bioavailability as organic-metal complexes are not readily transported across cell membranes $[30,36]$. Inorganic species, on the other hand, are readily available to the biota as the complexes are weak and dissociate rapidly to form free ions which bind to the transporters or are chelated by biotic ligands secreted by the organisms [37-40]. Table 1 shows the type of inorganic species formed at different salinities for five major metals.

While metal bio-availability, uptake, and toxicity decrease in presence of natural dissolved organic ligands, metals differ in their behavior at high salinities. For example, in case of cadmium, speciation is highly dependent on the complexing ligands. In river water it exists either as $\mathrm{CO}_{3}{ }^{-}$complex or free cation, and in oceanic waters it exists as highly soluble $\mathrm{CdCl}_{2}$, whereas in estuarine waters, it forms a strong $\mathrm{CdCl}^{+}$ complex which is biologically unavailable [41-43]. In case of silver, insoluble $\mathrm{AgCl}^{0}$ is formed in estuarine and oceanic waters, while under hypersaline conditions, soluble $\mathrm{AgCl}^{2-}$, $\mathrm{AgCl}_{3}{ }^{2-}$, and $\mathrm{AgCl}_{4}{ }^{3-}$ complexes are formed [44]. Soluble $\mathrm{HgCl}^{-}$and sparingly soluble $\mathrm{HgCl}_{2}$ are the predominant complexes of $\mathrm{Hg}$ at high salinities [45]. $\mathrm{HgCl}_{2}$ and the soluble silver-chloro complexes are lipophilic and can easily diffuse through cellular membranes [46]. $\mathrm{Zn}$ and $\mathrm{Cu}$ exist as $\mathrm{ZnCl}^{+}$and $\mathrm{CuCl}^{+}$which coprecipitate at higher salinities, due to decrease in the net negative charge on macromolecular suspended particles and therefore are not available for uptake. Unlike $\mathrm{Zn}$ (II) and $\mathrm{Cu}(\mathrm{II}), \mathrm{Fe}(\mathrm{II}), \mathrm{Co}(\mathrm{II}), \mathrm{Ni}(\mathrm{II})$, and $\mathrm{Mn}$ (II) form weak complexes with $\mathrm{Cl}^{-}$, that easily dissociate and can be taken up by organisms [28]. Table 2 summarizes the bioavailability of metal-chloro complexes.

The bioavailability of chlorocomplexes also depends upon the type of biotic ligands present. Biotic ligands are the receptors on an organism where metal binding takes place which results in the manifestation of its toxic effects [47]. Metal receptors and ion transporters such as $\mathrm{Na}$ (II) and $\mathrm{Ca}$ (II) transporters present on fish gill surfaces, algal membranes, phytoplankton membranes, and so forth act as biotic ligands [47]. Binding of metals to biotic ligands is unaffected by changes in salinity. However, metal complexes adsorbed to abiotic ligands such as sediments are desorbed with increase in salinity. Thus, biotic ligands render the metals unavailable to other organisms for uptake. For example, in case of silver, with increase in salinity, desorption of $\mathrm{Ag}(\mathrm{I})$ complexed with 
TABLE 1: Various inorganic complexes formed in natural waters, seawater, estuarine waters (variable salinity), and hypersaline waters. As haloarchaea inhabit hypersaline environments where inorganic ligands predominate, inorganic metal speciation is described. The availability of metal depends upon the kind of inorganic complex formed. Lipophilic soluble chlorocomplexes of $\mathrm{Hg}$ and Ag are easily available in hypersaline waters. Insoluble (precipitated) $\mathrm{ZnCl}_{2}$ and $\mathrm{CuCl}_{2}$ are unavailable to the organism. Fe (II), Co (II), $\mathrm{Ni}$ (II), and $\mathrm{Mn}$ (II) form weak complexes with $\mathrm{Cl}^{-}$that easily dissociate and can be taken up by organisms [28, 41-46].

\begin{tabular}{|c|c|c|c|c|}
\hline Metal & $\begin{array}{c}\text { Hypersaline } \\
\text { (5-35\% salinity) }\end{array}$ & $\begin{array}{c}\text { Sea water } \\
\text { (3.5\% salinity) } \\
\end{array}$ & $\begin{array}{c}\text { Estuarine } \\
\text { (variable salinity) }\end{array}$ & $\begin{array}{c}\text { River water/natural } \\
\text { water }\end{array}$ \\
\hline $\mathrm{Cd}$ & $\mathrm{CdCl}_{2}, \mathrm{CdCl}^{+}$ & $\mathrm{CdCl}^{+}$ & $\mathrm{CdCl}_{2}, \mathrm{CdCl}^{+}$ & $\mathrm{Cd}^{2+}, \mathrm{CdCO}_{3}$ \\
\hline $\mathrm{Ag}$ & $\begin{array}{c}\mathrm{AgCl}^{0}, \mathrm{AgCl}^{2-} \\
\mathrm{AgCl}_{3}{ }^{2-}, \mathrm{AgCl}_{4}{ }^{3-}\end{array}$ & $\mathrm{AgCl}^{0}, \mathrm{AgHS}^{0}$ & $\begin{array}{c}\mathrm{AgCl}^{0}, \mathrm{AgHS}^{0} \\
\mathrm{AgCl}^{2-}, \mathrm{AgCl}_{3}^{2-} \\
\mathrm{AgCl}_{4}^{3-}\end{array}$ & $\mathrm{Ag}^{+}, \mathrm{AgCl}^{0}$ \\
\hline $\mathrm{Hg}$ & $\begin{array}{l}\mathrm{HgCl}^{0}, \mathrm{HgCl}^{-}, \\
\mathrm{HgCl}_{4}^{2-}\end{array}$ & $\mathrm{HgCl}^{-}$ & $\begin{array}{c}\mathrm{HgCl}^{0}, \mathrm{HgCl}^{-} \\
\mathrm{HgCl}_{4}{ }^{2-}\end{array}$ & $\begin{array}{c}\text { Mixture of } \mathrm{Hg}- \\
\text { chloro and hydroxy } \\
\text { complex }\end{array}$ \\
\hline $\mathrm{Zn}$ & $\mathrm{ZnCl}_{2}$ & $\begin{array}{c}\mathrm{Zn}^{2+}, \mathrm{ZnCl}_{2} \\
\mathrm{ZnCO}_{3} \\
\mathrm{Zn}\left(\mathrm{HCO}_{3}\right)_{2} \\
\mathrm{Zn}(\mathrm{OH})_{2}, \mathrm{ZnSO}_{4}\end{array}$ & $\begin{array}{c}\mathrm{Zn}^{2+}, \mathrm{ZnCl}_{2} \\
\mathrm{ZnCO}_{3} \\
\mathrm{Zn}\left(\mathrm{HCO}_{3}\right)_{2} \\
\mathrm{Zn}(\mathrm{OH})_{2}, \mathrm{ZnSO}_{4}\end{array}$ & Hydrated $\mathrm{Zn}^{2+}$ \\
\hline $\mathrm{Cu}$ & $\mathrm{CuCl}_{2}$ & $\begin{array}{c}\text { Carbonato and } \\
\text { hydroxy complexes }\end{array}$ & $\begin{array}{c}\mathrm{CuCl}_{2} \text {, Carbonato } \\
\text { and hydroxy } \\
\text { complexes }\end{array}$ & $\mathrm{Cu}^{2+}, \mathrm{CuCO}_{3}$ \\
\hline
\end{tabular}

TABLE 2: Bioavailability of metal-ligand complexes in hypersaline conditions depending upon the nature of the complex formed.

\begin{tabular}{ll}
\hline Availability & Type of complex \\
\hline \multirow{3}{*}{ Biologically unavailable } & (i) Strong insoluble inorganic metal-chloro complexes $\left(\mathrm{ZnCl}_{2}, \mathrm{CuCl}_{2}\right)$ \\
& (ii) Soluble not easily dissociable metal-chloro complexes $\left(\mathrm{CdCl}_{2}\right)$ \\
& (iii) Biosorbed metal complexes (i.e., metals sorbed on a biotic ligand) \\
\hline Biologically available & (i) Strong soluble lipophilic inorganic metal-chloro complexes $\left(\mathrm{AgCl}^{2-}, \mathrm{AgCl}_{3}{ }^{2-}, \mathrm{AgCl}_{4}{ }^{3-}\right.$, and $\left.^{-} \mathrm{HgCl}_{2}\right)$ \\
& (ii) Weak metal-chloro complexes (Fe, Co, Ni, and Mn) \\
& (iii) Metal complexes sorbed to abiotic ligands \\
\hline
\end{tabular}

suspended sediments and formation of soluble chlorocomplexes, which are bioavailable have been observed. However, biosorbed $\operatorname{Ag}(\mathrm{I})$ is not influenced by the increase in salinity, and desorption of $\mathrm{Ag}(\mathrm{I})$ does not occur [48].

The toxicity of a metal to microorganisms does not have a linear relationship with its concentration, and it depends strongly upon chemical speciation $[49,50]$. For certain metals such as $\mathrm{Zn}(\mathrm{II})$ and $\mathrm{Cu}(\mathrm{II})$, complexation with chloride ions may result in precipitation at high salinities. Therefore, these complexes are not available to micro-organisms for uptake. However, metals such as $\mathrm{Hg}(\mathrm{II}), \mathrm{Ag}(\mathrm{II}), \mathrm{Fe}(\mathrm{II}), \mathrm{Co}(\mathrm{II}), \mathrm{Ni}(\mathrm{II})$, and $\mathrm{Mn}$ (II) either form lipophilic soluble chlorocomplexes or weak chlorocomplexes that dissociate easily and are thus available to organisms for uptake. Therefore, while studying metal resistance in haloarchaea, metal speciation and the bioavailability of metals should be taken into consideration.

\section{Metal Resistance}

Organisms inhabiting the metal polluted environments develop resistance mechanisms that enable efficient detoxification and transformation of toxic forms to nontoxic forms. The majority of bacteria and eukarya tolerate metals by a reduced influx/enhanced efflux [51, 52] or enzymatic detoxification sometimes followed by volatilization [6, 53]. Intracellular compartmentalization is observed only in eukaryotes [51]. Figure 1 shows the various mechanisms of metal resistance exhibited by all the three domains of life.

Intracellular chelation (Figure 1) by a variety of cysteine(Cys-) rich metal-binding peptides like glutathione (GSH) and proteins like metallothioneins (MTs) and phytochelatins (PCs) also confers resistance to metals in many microbes [54]. MTs are genetically coded small molecular weight polypeptides that are classified based upon the number of Cys residues [55]. They typically have two Cys-rich domains that bind heavy metals through mercaptide bonds, giving these proteins a dumbbell-shaped conformation comprising an $\mathrm{N}$-terminal $\beta$-domain that usually binds 3 metal ions and a C-terminal $\alpha$-domain that binds 4 metal ions [56, 57]. PCs comprise ( $\gamma$-GluCys $)_{n}$-Gly where $n$ is usually in the range of 2 to 5 . They are enzymatically synthesized by PC synthase using GSH as the substrate $[58,59]$. The thiol group of the cysteine residue in PCs sequesters heavy metals. Apart from these cysteine-rich peptides, cells may secrete other metal sequestering proteins like siderophores and DNA-binding protein from nutrient starved cells (Dps) 


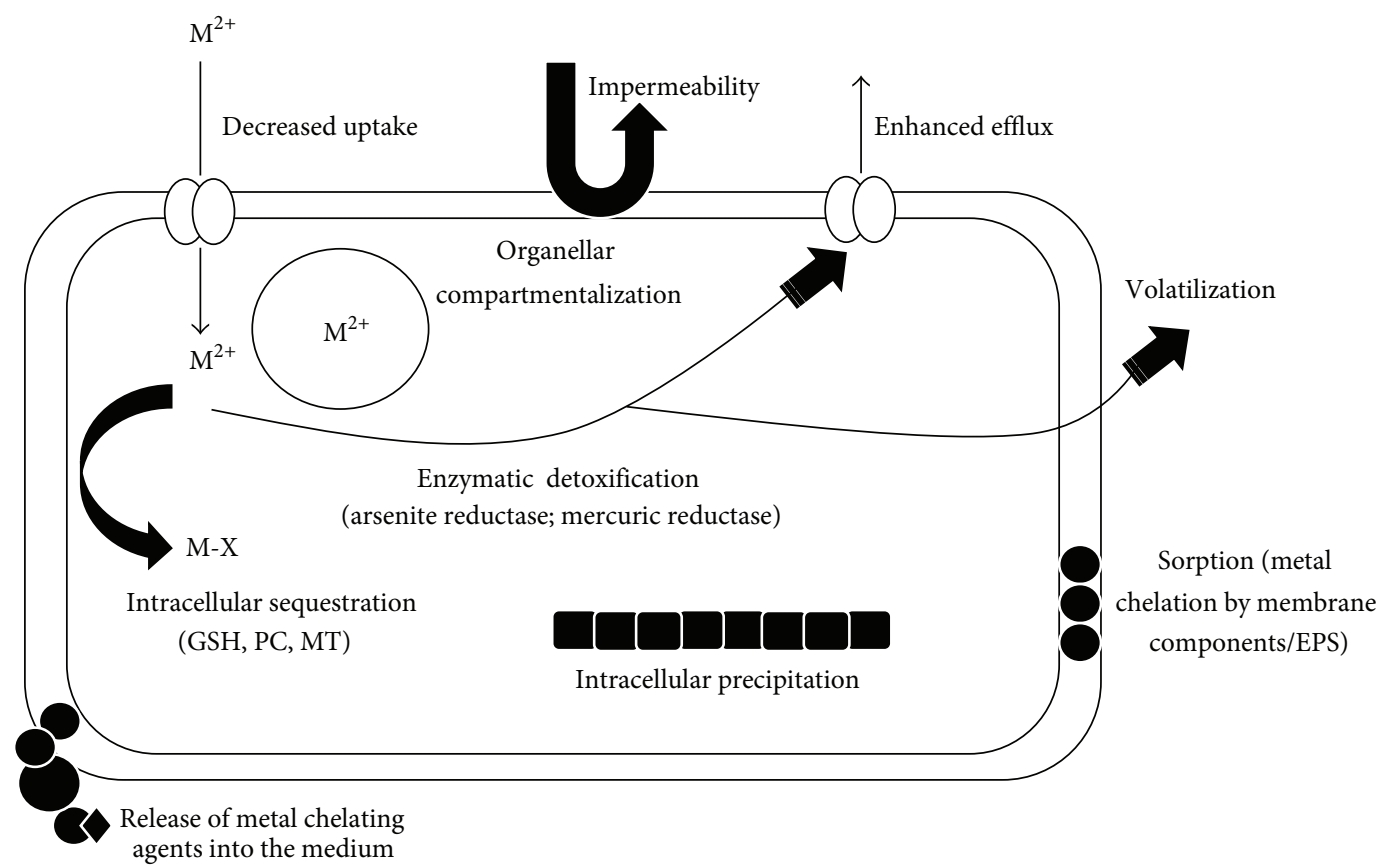

FIGURE 1: General mechanisms adapted by bacteria, eukaryotes, and archaea for metal resistance. All the three domains exhibit sorption of metals, volatilization, release of metal chelating compounds in the medium, enhanced efflux, impermeability, decreased uptake, enzymatic detoxification, and intracellular chelation as mechanisms for metal resistance. Organellar compartmentalization is observed only in eukaryotes, with the exception of magnetosomes in magnetotactic bacteria.

(Figure 1). Siderophores are a class of low molecular weight iron chelating compounds which store iron and are overexpressed during conditions of stress or iron deficiency [60]. They are chemically diverse and generally possess oxygen-donor-type chelating functional groups [61]. Once chelated, the Fe-siderophore complex is transported to the periplasm through the energy-coupled transport involving TonB dependent transporters (TBDT) and the inner membrane TonB-complex, composed of TonB, ExbB, and ExbD. The Fe-siderophore can then be transported to the cytoplasm through $\mathrm{ABC}$ transporters like ferrichrome or permeases [62]. TonB protein is responsible for transducing cytoplasmic membrane energy to the outer membrane which results in TonB associating with or changing its affinity towards the outer membrane, while ExbB/D components antagonize this association or affinity of TonB to cytoplasmic membrane [63]. Siderophores have also been shown to chelate metals other than Fe [62]. Dps are structurally homologous to ferritins, the primary iron storage/detoxification proteins, are usually expressed in response to excess of iron, and are found in all three domains of life [64]. These proteins have pores that are lined with acidic residues that bind cations like Fe(II) [65]. The binding of $\mathrm{Fe}(\mathrm{II})$ to Dps protects cells from oxidative stress by inhibiting the Fe-catalyzed production of hydroxyl radicals [66].

Haloarchaea have $\gamma$-glutamylcysteine $(\gamma$-GC) $[67,68]$ which is analogous to GSH and is involved in maintaining a reducing environment within the cell, overcoming oxidative and disulfide stress and detoxification of xenobiotics [69]. The thiol group of cysteine in $\gamma$-GC can chelate the toxic metal ions thereby conferring resistance. A unique phenomenon observed in archaea is the heavy metal-induced multimerization of metal chelating proteins such as CutA- and DpsAlike proteins that result in the precipitation of the proteinmetal ion complex [23]. This precipitate resolubilizes and the multimers disintegrate when the metal stress decreases $[70,71]$. Although these proteins are known to be involved in divalent metal tolerance in bacteria and eukaryotes, the multimerization of these proteins has been observed only in archaea. The aspartate residue in position 48 has been found to be critical for metal-induced multimerization and metal ion binding of CutA protein in Pyrococcus horikoshii. Substitution of Asp48 with alanine decreases the amount of aggregate formation [70]. Similarly, the multimeric nonhaem ferritin DpsA-like protein of Halobacterium salinarum ensued from an assembly of 12 units and was found to sequester iron in response to the oxidative stress exerted by excess iron [72]. This protein was downregulated under irondeficient conditions unlike the other $d p s$ that are upregulated under these conditions. It exhibits the features of nonhaem bacterial ferritins that are expressed to sequester the excess iron. Their expression is repressed under conditions of iron starvation [73]. Overexpression of siderophores in haloarchaea may increase chelation in case of iron deficiency. On the other hand, repression of these siderophores in presence of excess iron may avoid uptake $[68,74]$. MTs are absent in archaea [23].

Biosorption of metals by the organisms at the surface or by the exopolysaccharides (EPS) secreted to form the biofilms enables organisms to tolerate metals $[75,76]$. Biofilm 
forming organisms exhibit an altered phenotype with respect to growth rate and gene transcription [77]. Haloarchaea synthesize EPS as a protective mechanism for survival under adverse conditions such as nutrient starvation, temperature fluctuation, and presence of toxic compounds [78]. Similarly the hyperthermophilic archaeon, Archaeoglobus fulgidus, was found to form a biofilm in response to toxic concentrations of metals, where the toxic metal was proposed to be trapped within the EPS matrix [78]. Thus, it is probable that under metal stress, haloarchaea may secrete EPS to make the cell impermeable to metals. In a study by Kawakami et al. (2007) [79], it has been found that Halobacterium salinarum CCM 2090 has a $\mathrm{Ca}(\mathrm{II})$-dependent aggregation system, where the $\mathrm{Ca}$ (II) binds to certain aggregation factors present on the cell surface and induces ionic crossbridging between the EPS resulting in aggregation of the haloarchaeal cells. The presence of certain receptor proteins on the cell surface that interact with $\mathrm{Ca}(\mathrm{II})$ to form cell aggregates/flocs has also been demonstrated [79]. Four haloarchaeal genomes, Haloquadratum walsbyi, Haloarcula marismortui, Haloterrigena turkmenica, and Halobacterium sp. strain NRC-1, have been annotated with $c b p$ encoding the cell surface calciumbinding acidic-repeat protein [80-83] that has been proposed to be the factor involved in $\mathrm{Ca}(\mathrm{II})$-dependent aggregation, although its role in this process remains to be demonstrated. A similar dependence on $\mathrm{Ca}(\mathrm{II})$ and/or $\mathrm{Fe}(\mathrm{II})$ for biofilm formation is observed in Vibrio cholerae [84] and Pseudomonas aeruginosa [85]. $\mathrm{Ca}$ (II) is the twentieth element found in the fourth row of the periodic table, which could be replaced by other transition metal ions such as $\mathrm{Mn}(\mathrm{II})$, $\mathrm{Cr}(\mathrm{II}), \mathrm{Fe}(\mathrm{II}), \mathrm{Co}(\mathrm{II}), \mathrm{Ni}(\mathrm{II}), \mathrm{Cu}(\mathrm{II})$, and $\mathrm{Zn}(\mathrm{II})$, belonging to the same row. The distinctive electronic configuration of these metals, characterized by preferential filling of the $4 \mathrm{~s}$ subshell before the $3 \mathrm{~d}$ subshell, may be responsible for these metals substituting $\mathrm{Ca}$ (II) during aggregate formation [79]. Thus, tolerance to these metals may be mediated through binding with EPS. This view is supported by the observation that there is no aggregation in presence of certain other metals lacking this electronic configuration, such as $\mathrm{Mg}(\mathrm{II})$ and Sr(II) (alkali earth metals), Mo(II), Cd(II) and Sn(II) (fifth period), and $\mathrm{Hg}(\mathrm{II})$ and $\mathrm{Pb}(\mathrm{II})$ (sixth period) [79]. Aggregation in haloarchaeal cells results in formation of nonadherent floating multicellular aggregates which is different from biofilm formation, where the adherent multicellular structures are attached to diverse surfaces [86]. Recently, biofilm formation involving EPS (glycoconjugates and extracellular DNA) matrix was demonstrated in five haloarchaeal genera, Halobacterium, Haloferax, haloalkaliphilic Halorubrum, psychrotolerant Halorubrum, and a new genus of psychrotolerant haloarchaea isolated from Deep Lake, Antarctica [87]. Here $\mathrm{Ca}(\mathrm{II})$ ion did not have an effect on surface adhesion, suggesting the involvement of flagellar-twitching-motilityinduced cellular aggregation and adhesion to substratum. Biofilm formation by other archaea like Pyrococcus furiosus, Sulfolobus solfataricus, and Methanococcus maripaludis involves cellular appendages such as archaeal type IV pili [8890]. These are similar in structure and function to the type IV pili present in bacteria that facilitate cell-cell interactions, surface adhesion, and motility [91]. Archaeal type IV pili have been shown to be involved in biofilm formation by Haloferax, Halobacterium, and Halorubrum [87, 92, 93]. The biofilm formed may trap the metals within the EPS matrix and prevent the diffusion of metals inside the cell, thus conferring resistance to haloarchaea.

Most bacteria carry the resistance determinants for metals as operons, on their plasmids [94]. The metal resistance operons usually include genes for transporters and an enzyme for detoxification. Haloarchaea exhibit resistance mechanisms similar to those of bacteria. The ars operon conferring arsenite and arsenate resistance in Halobacterium sp. strain NRC-1 is present on one of its two plasmids [83]. A comparative genome analysis of bacteria and archaea revealed some common elements responsible for maintenance of metal homeostasis and resistance. $\mathrm{P}_{1 \mathrm{~B}}$-type ATPases involved in cation transport with a high diversity in the $\mathrm{N}$ terminal metal-binding motifs were found to be distributed throughout the bacterial and archaeal lineages [10]. Genome of Halobacterium salinarum NRC-1 was found to carry two distinct phylogenetic clusters, CopA1 (Cu(II) influx) and CopA2 (Cu(II) influx and efflux). These clusters were also found to span the entire diversity of the bacterial domain. Coombs and Barkay (2005) [10] have proposed that variation in $\mathrm{N}$-terminal metal-binding motifs does not affect the metal translocation function of $\mathrm{P}_{1 \mathrm{~B}}$-type ATPases and therefore concluded that divergence in consensus sequence of the $\mathrm{N}$-terminal metal-binding motif might have been tolerated during evolution [10,83]. But this is just one of the few studies on metal homeostasis in archaea. Similar studies understanding the phylogenetic variation within the family Halobacteriaceae will enable a better understanding of metal homeostasis, by giving a snapshot of substrate specificity, variation in active sites, and so forth [23].

3.1. Operons in Metal Resistance. Many metal resistance determinants have been characterized in the bacterial system [95-105], of which mer operon for mercury resistance [95], ars for arsenic resistance [97, 98], and cad operon for cadmium resistance [99] have been extensively studied. All archaea except haloarchaea have been shown to carry such metal resistance determinants $[106,107]$. The most comprehensively studied among these are the mer operon of the thermoacidophilic archaeon Sulfolobus solfataricus $[108,109]$, ars operon of acidophilic archaeon Ferroplasma acidarmanus Fer1 [110] and Thermoplasma acidophilum [111], and the cop operon for copper resistance of Sulfolobus solfataricus P2 [112-114]. Although many heavy metal transporters like CbiNOQ, HemUV, NosFY, and so forth are present in haloarchaea, their arrangement in an operon has not been shown, except for the ArsA ATPase transporter as a part of ars operon for arsenic resistance in Halobacterium sp. strain NRC-1 [21].

Most haloarchaea have large plasmids in addition to their genomes (chromosomes) known as minichromosomes/megaplasmids. These minichromosomes harbor genes for antibiotic resistance or metal resistance that may be essential for haloarchaeal survival [115]. The pNRC100, one 
of the two minichromosomes of model organism Halobacterium sp. strain $N R C-1$, harbors the ars $A D R C$ gene cluster, responsible for conferring arsenate $(\mathrm{As}(\mathrm{V}))$ and arsenite $(\mathrm{As}(\mathrm{III}))$ /antimonite $(\mathrm{Sb}(\mathrm{III}))$ resistance [83]. A fifth gene for arsenic resistance, $\operatorname{ars} B$, is present on the main chromosome. The ars $A D R C$ operon was annotated for As(III) transport due to its homology to previously characterized genes [116], but later, by gene knockout studies, it was shown to confer resistance to $\mathrm{As}(\mathrm{III})$ and $\mathrm{Sb}(\mathrm{III})$ [21]. As(V) can be taken up by the cells through phosphate transporters (pit/pst) and As(III) by aquaglycerophorins (glycerophorin membrane transport proteins) [117] or hexose transporters [118]. As $(\mathrm{V})$ is then converted to As(III) by arsenate reductase encoded by ars $C$ [119]. ars $A$ codes for $\mathrm{P}_{1 \mathrm{~B}}$-type ATPase transporters that help in extrusion of $\mathrm{As}(\mathrm{III}) / \mathrm{Sb}$ (III) from the cell. $\operatorname{ars} R$ and $\operatorname{ars} D$ encode trans-acting repressors of the operon. ArsR and ArsD bind to $\mathrm{As}(\mathrm{III}) / \mathrm{Sb}(\mathrm{III})$ resulting in expression of the ars $A$ and ars $C$. Arsenate reductase encoded by $\operatorname{ars} C$ is expressed weakly in Halobacterium sp. strain NRC-1, and therefore deletion of ars $C$ and $\operatorname{ars} A D R C$ was found to be ineffective in conferring arsenate sensitivity [21]. The operon $\operatorname{ars} A D R C$ was found to be inducible by arsenite and antimonite [21].

In bacteria, ArsB, an inner membrane protein, along with ArsA, the membrane-bound anion-transporting ATPase, forms the anion-conducting channel for arsenite extrusion [120]. Halobacterium sp. strain NRC-1 also harbors both arsA in ars operon on the megaplasmid pNRC100 and arsB on the main chromosome. However, arsB was found to play no role in arsenic resistance in this organism. Thus, it has been proposed that Halobacterium sp. strain NRC-1 harbors a novel transporter unrelated to ArsB but with a similar function [21]. Arsenic resistance in the Gram-negative acidophilic bacterium Acidthiobacillus ferrooxidans is determined by the chromosomally located arsCRBH operon comprising four genes [121]. The unique and common feature between the arsADRC and arsCRBH operons is the bidirectional nature of translation; that is, the ars $\mathrm{AD}$ and arsCR genes are translated in an opposite direction to arsRC and arsBH, respectively [21, 121] (Figure 2).

In Halobacterium sp. strain NRC-1, a second arsenite resistance operon, $\operatorname{ars} R 2 M$, is present upstream of $\operatorname{ars} A D R C$ on pNRC100 (Figure 2), where arsR2 is constitutively expressed while $\mathrm{As}(\mathrm{III}) / \mathrm{Sb}$ (III) induce the expression of $\operatorname{ars} M$ [21]. The arsR2 is analogous to arsR and ars $M$ encodes a putative As(III)-methyltransferase very similar to human methyltransferases and S-adenosyl methioninedependent methyltransferases of Magnetospirillum magnetotacticum. ArsM is involved in converting As(III) to methylated species like dimethylarsinate (DMA), trimethylarsine oxide (TMAO), or trimethylarsine (TMA) gas [122]. Deletion of ars $M$ exhibited as increased sensitivity to arsenite but not towards arsenate or antimonite [21]. Thus, two possible mechanisms of As(III) resistance have been proposed to be conferred by ars $M$. First, the generation of a concentration gradient results in the movement of methylated arsenite (negatively charged/uncharged) out of the cell. Second, the volatile trimethylarsine formed diffuses out of the cell thus eliminating As(III) [123, 124]. Although arsenite methylation as a resistance mechanism is present in bacteria, ars $M$ gene functions independently and is not a part of ars operon [123]. However, in Halobacterium sp. strain NRC-1, the arsM gene is present as a part of the ars $R 2 M$ operon involved in arsenite resistance [21].

Mercury resistance in archaea and bacteria is conferred by the mer operon involved in detection, regulation, transport, and reduction of $\mathrm{Hg}(\mathrm{II})[125,126]$. One of the best studied mercury resistance operons in Archaea is the merRHAI operon of thermoacidophilic archaeon Sulfolobus solfataricus $[108,109]$. The operon is under the control of the regulator MerR, which represses the operon in absence of $\mathrm{Hg}$ (II) and enhances transcription in its presence. $\mathrm{MerH}$ is the metallochaperone with a TRASH (trafficking, resistance, and sensing of heavy metals) domain that binds $\mathrm{Hg}(\mathrm{II})$, and MerA is the mercuric reductase for reduction and detoxification to volatile $\mathrm{Hg}(0)[108,109]$. Some mer operons carry additional mer genes, notably merB, an organomercurial lyase, that cleaves the $\mathrm{C}-\mathrm{Hg}$ bonds of organomercurials, and the released $\mathrm{Hg}(\mathrm{II})$ is reduced to $\mathrm{Hg}(0)$ by MerA [126]. Among all haloarchaeal genomes sequenced to date, only Halobacterium sp. strain NRC-1 and Haloterrigena turkmenica have been annotated with merA and merB genes, respectively [83, 127].

3.2. Transporters in Metal Resistance. Membrane transporters may act as the first line of defense against toxic or heavy metals. In order to exert their toxicity, metals need to gain entry within the cell. Thus, the organism may downregulate the transporters responsible for influx or induce the expression of efflux pumps to enable faster removal of toxic metals from within the cell [76]. The use of these membrane transporters and efflux pumps is one of the most common mechanisms of resistance to inorganic ions in microbes.

Both influx and efflux types of transporters for various metals have been annotated in all haloarchaeal genomes sequenced to date (Table 3 ). The following membrane transporters have been implicated in haloarchaeal metal resistance.

3.2.1. $P_{1 \mathrm{~B}}$-Type ATPases. The $\mathrm{P}_{1 \mathrm{~B}}$-type ATPases are a large family of integral membrane proteins driven by ATP hydrolysis [128]. Members of this family are of vital importance to all kingdoms of life, as they generate and maintain electrochemical gradients across membranes by transporting cations and heavy metals [129]. A wide variety of heavy metal ions like $\mathrm{Mg}(\mathrm{II}), \mathrm{Ca}(\mathrm{II}), \mathrm{Cu}(\mathrm{II}), \mathrm{Ag}(\mathrm{II}), \mathrm{Zn}(\mathrm{II})$, and $\mathrm{Cd}(\mathrm{II})$ act as substrates to these ATPases [130]. These transporters serve the purpose of uptake (import) of essential elements and efflux (export) of toxic elements, thus conferring resistance to the expelled metal ion $[131,132]$. All haloarchaeal genomes have been annotated with metal transporting ATPases.

A putative Cd(II)-efflux ATPase was annotated on Halobacterium sp. strain NRC-1 genome [83]. In a system level analysis of Halobacterium sp. strain NRC-1, the functionality and role of such transporters in metal resistance was shown [22]. They exhibited upregulation of $y v g X$, a $\mathrm{P}_{1 \mathrm{~B}}$-type ATPase, in response to $\mathrm{Cu}(\mathrm{II})$ and $\mathrm{Zn}(\mathrm{II})$ metal stress. In bacteria, the $y v g X$ family is known to encode two kinds of CopA 


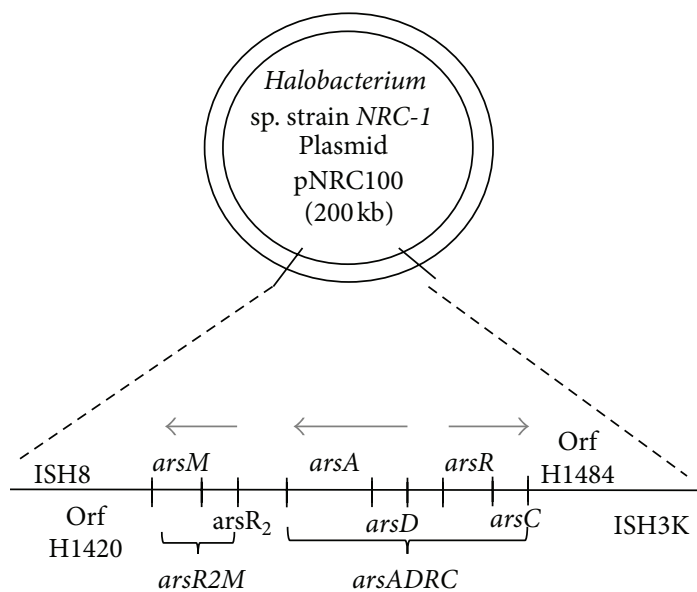

(a)

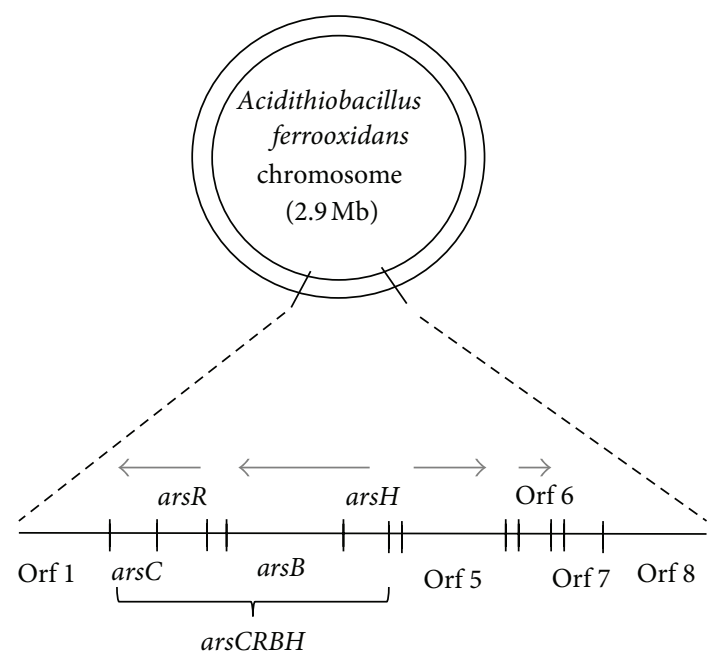

(b)

FIgURE 2: Arsenic resistance is determined by the presence of ars operon, which codes for an arsenite $\mathrm{P}_{1}$-type ATPases transporter ArsA/ArsB, an arsenate reductase $\mathrm{ArsC}$, and arsenite responsive repressors ArsD and ArsR. The arsADRC and arsR2M operons are present on the plasmid in haloarchaeon Halobacterium sp. strain NRC-1 (a). The acidophilic bacterium Acidithiobacillus ferrooxidans has chromosomally encoded $\operatorname{ars} C R B H(b)$. The unique feature of these operons is the bidirectional nature transcription.

TABLE 3: Annotated transporters for various metals in haloarchaeal genomes. Ten haloarchaeal genomes have been completely sequenced while others are partially sequenced. All these organisms have been annotated with transporters belonging to the following type of transporters-cation efflux type, $\mathrm{P}_{1 \mathrm{~B}}$-type ATPases, cation diffusion facilitator (CDF) family, and ATP-binding cassette (ABC) family. The most abundant transporters were for iron followed by copper. Only one haloarchaeon, Halogeometricum borinquense, was annotated with silver transporters [135].

\begin{tabular}{|c|c|c|c|c|c|c|c|c|c|c|c|c|}
\hline Transporters for metals & H.s. & H.m. & H.v. & H.w. & H.l. & H.mu. & H.u. & H.b. & H.t. & H.j. & N.p. & N.m. \\
\hline Copper & + & + & + & + & + & + & + & + & $\cdot$ & + & + & + \\
\hline Iron & + & + & + & + & + & + & + & + & + & + & + & + \\
\hline Manganese & . & + & + & + & + & . & . & . & + & . & + & + \\
\hline Zinc & + & + & + & + & + & + & + & . & + & + & + & + \\
\hline Cobalt & + & + & + & + & + & + & + & + & + & + & + & + \\
\hline Nickel & + & $\cdot$ & $\cdot$ & + & $\cdot$ & . & . & + & . & + & + & + \\
\hline Molybdenum & . & + & + & $\cdot$ & . & . & . & . & . & . & $\cdot$ & $\cdot$ \\
\hline Arsenic & + & + & + & + & + & + & + & . & + & + & . & $\cdot$ \\
\hline Cadmium & + & + & $\cdot$ & + & . & · & · & $\cdot$ & $\cdot$ & . & + & + \\
\hline Magnesium & . & + & + & . & . & . & + & + & . & + & . & $\cdot$ \\
\hline Silver & . & . & $\cdot$ & $\cdot$ & $\cdot$ & . & . & + & . & . & . & . \\
\hline
\end{tabular}

(+) present; (·) not annotated yet; H.s., Halobacterium sp. strain NRC-1; H.m., Haloarcula marismortui; H.v., Haloferax volcanii; H.w., Haloquadratum walsbyi; H.l., Halorubrum lacusprofundi; H.mu., Halomicrobium mukohataei; H.u., Halorhabdus utahensis; H.b., Halogeometricum borinquense; H.t., Haloterrigena turkmenica; H.j., Halalkalicoccus jeotgali; N.p., Natronomonas pharaonis; N.m., Natrialba magadii.

proteins, CopA1 and CopA2 [133]. CopA1 is essential for copper influx and tolerance, while CopA2 is involved in the influx/efflux of $\mathrm{Cu}$ and its transport to $\mathrm{Cu}$-containing enzyme cytochrome oxidase c $[133,134]$. A diverse range of organisms contain CopA2-like proteins, suggesting that coding genes appeared early in evolution via gene duplication or horizontal transfer but were kept only in some organisms for a specific biological function [134]. A comparative genome analysis for ATPases in bacteria and archaea showed the preference for CopA2 over CopA1 [10]. It has been proposed that CopA2 may represent the ancestral form of CopAl protein that may have coevolved with the other metal influx proteins [10]. The $y v g X$ of Halobacterium sp. strain NRC-1 was found to be more specific for $\mathrm{Cu}(\mathrm{II})$ efflux family as the $\Delta y v g X$ strain was susceptible to $\mathrm{Cu}(\mathrm{II})$ and not to $\mathrm{Zn}$ (II) or $\mathrm{Co}(\mathrm{II})$ and therefore belongs to the CopA2 family of proteins. CopA2 is also found in other haloarchaea like Haloarcula marismortui, Haloarcula hispanica, and Haloquadratum walsbyi [135].

The As(III)/Sb(III) transporting $\mathrm{P}_{1 \mathrm{~B}}$-type ATPase, ArsA discussed in Section 3.1, is present in almost all haloarchaea sequenced to date, including Halobacterium sp. strain NRC1, Halalkalicoccus jeotgali, Haloarcula hispanica, Natrialba magadii, Haloarcula marismortui, Haloquadratum walsbyi, and Natronomonas pharaonis [135]. ArsB was found to play 
no role in arsenite resistance in Halobacterium sp. strain NRC-1 [21].

Heavy metal cation-transporting $\mathrm{CPx} \mathrm{P}_{1 \mathrm{~B}}$-type ATPases are of two types, that is, $\mathrm{Cu}$-CPx-type-ATPases involved in efflux of monovalent cations, $\mathrm{Cu}(\mathrm{I})$ and $\mathrm{Ag}(\mathrm{I})$, and $\mathrm{Zn}-\mathrm{CPx}-$ type ATPases involved in the efflux of divalent cations of $\mathrm{Zn}$, Cd and Pb [137-139]. However, Cu-CPx-type ATPases have also been shown to be involved in uptake of copper to meet cellular demands $[140,141]$. The $c p x$ gene that encodes CPx $\mathrm{P}_{1 \mathrm{~B}}$-type ATPases was found to be downregulated by $\mathrm{Fe}(\mathrm{II}), \mathrm{Cu}(\mathrm{II})$, and $\mathrm{Ni}(\mathrm{II})$ to avoid influx in Halobacterium sp. strain NRC-1 [22]. This mechanism of resistance involving the downregulation of uptake systems avoids toxic metal buildup within the cell.

\subsubsection{Cation Diffusion Facilitators (CDF Family) Metal Trans-} porters. The CDF family of transport proteins is ubiquitously present in all three domains of life [142]. Although CDFs are primarily $\mathrm{Zn}(\mathrm{II})$ efflux pumps, bacterial CDFs have been shown to transport $\mathrm{Hg}(\mathrm{II}), \mathrm{Pb}(\mathrm{II}), \mathrm{Zn}$ (II), $\mathrm{Co}(\mathrm{II}), \mathrm{Fe}(\mathrm{II})$, and $\mathrm{Cd}(\mathrm{II})$ from the cytoplasm to the outside of the cell or into subcellular compartments $[132,143]$. Based upon their substrate specificity, CDFs have been classified as $\mathrm{Zn}$ (II)-CDF, $\mathrm{Fe} / \mathrm{Zn}-\mathrm{CDF}$, and Mn-CDF [144]. They usually possess six transmembrane domains (TMDs) with a cytoplasmic $\mathrm{N}$ - and C-terminal and a histidine loop of variable length between TMD IV and V $[145,146]$. The amphipathic domains TMD I, II, V, and VI are involved in metal transfer and are the most conserved, while the hydrophobic TMD III and IV are critical for zinc specificity and mutations within these domains alter substrate specificity [144]. All the proteins of this family of transporters possess a characteristic cation efflux C-terminal domain [147]. These kinds of transporters serve as secondary cation filters in bacteria [132]. The genome of Halobacterium sp. strain NRC-1 was annotated with putative CDF Cd (II) transporter $Z n t X$, which confers resistance against $\mathrm{Ni}(\mathrm{II})$, $\mathrm{Cu}(\mathrm{II})$, and $\mathrm{Zn}$ (II) besides $\mathrm{Cd}(\mathrm{II})$ [22]. The role of $\mathrm{Znt}$ family of CDFs in $\mathrm{Cu}$ (II) and/or $\mathrm{Zn}$ (II) homeostasis and resistance has been discussed in detail by Haney et al. (2005) [145]. The upregulation of $Z n t A$ in response to heavy metals ( $\mathrm{Cu}$ and/or $\mathrm{Zn}$ ) and poor growth of $\Delta z n t A$ strain in presence of $\mathrm{Ni}(\mathrm{II}), \mathrm{Cu}(\mathrm{II}), \mathrm{Zn}$ (II), and $\mathrm{Cd}(\mathrm{II})$ have confirmed the role of this transporter in metal resistance [22]. The broad specificity of this transporter to various metals has been putatively attributed to the preference of metals by $z n t A$ based on charge and species rather than size [148]. Haloarcula hispanica and Haloarcula marismortui have also been annotated with ZntA for $\mathrm{Zn}$ (II) transport. A putative CDF family protein has also been found on the chromosome of Natrialba magadii for inorganic metal ion transport [135].

3.2.3. ATP-Binding Cassette (ABC) Transporters. The multisubunit $\mathrm{ABC}$ transporters are one of the largest protein families with a variety of physiological functions. These transporters are ubiquitously present in all living forms from bacteria to eukaryotes including archaea. They are involved in various functions such as nutrient uptake [149], oligopeptide and protein transport [150], metal extrusion [151, 152], and drug efflux $[153,154]$.

Although many ABC transporter genes for a variety of substrates have been annotated in all the 10 haloarchaeal genomes sequenced to date, experimentally, very few have been shown to be functional. ABC transporters for sugar and polypeptide have been found in Haloferax volcanii [155], Haloarcula marismortui [81], Halobacterium sp. NRC1 [83], Natronomonas pharaonis [156], and Haloquadratum walsbyi [80]. All haloarchaea possess at least one copy of metal ion $\mathrm{ABC}$ transporter. Some of the ABC transporters in Halobacterium sp. NRC-1 with their functions are listed in Table 4. Many of the ABC transporters are metal ion transporters such as cbiNOQ for Co(II) transport [157], hem $U V$ for iron uptake $[158,159]$, nosFY for copper [160], and zurMA for zinc transport (Figure 3). Although most of the $\mathrm{ABC}$ transporter proteins exhibit stringent specificity towards their substrate, a few, such as phosphate transporters, oligopeptide transporters, and dipeptide transporters, have been shown to have multiple specificities and were found to be differentially regulated by more than one metal ion. This has been proposed to facilitate transport of metal ions in addition to their usual function [150]. Kaur et al. (2006) [22] have shown that deletion of transporters like phoX (phosphate transport), appA (peptide transport), and $y c d H(\mathrm{Mn}(\mathrm{II})$ transport) along with two putative subunits of $\mathrm{Fe}(\mathrm{II})$ transport system does not prove deleterious for Halobacterium sp. NRC-1. Due to the large repertoire of ABC transport proteins, they concluded that deletion/mutation of a single $\mathrm{ABC}$ transporter is easily managed by the organism by substituting the deleted/mutated $\mathrm{ABC}$ transporter product with functional ABC transporter product of similar role.

The differential regulation of all three classes of metal transporters discussed above is in congruence with the general norm of micro-organisms utilizing enhanced efflux or decreased influx to resist metals. However, the $\mathrm{P}_{1 \mathrm{~B}}$-type ATPases and CDF family have a greater role in maintaining metal homeostasis than the $\mathrm{ABC}$ transporters in haloarchaea [22].

3.3. Transcriptional Changes in Response to Metal Stress. Under unfavourable conditions of growth, all organisms make adjustments at the system level to overcome the stress imposed by the stressor. Presence of heavy metals in their environment triggers global transcriptional regulations either to prevent their entry into the cell or to transform the metal to nontoxic form. This response can be transitory, with perturbations of a few genes within minutes of metal exposure, but once the cell acclimatizes to the new environment, the transcript levels of some early response genes return to preperturbation levels. The early response to a stressor usually results in the upregulation of transcription and translation. As a consequence, the transcripts damaged due to the stressor are replaced and new proteins are synthesized [161, 162].

In haloarchaea, only one study on transcriptional changes in response to heavy metal stress (Fe(II), $\mathrm{Cu}(\mathrm{II}), \mathrm{Co}(\mathrm{II})$, $\mathrm{Ni}(\mathrm{II}), \mathrm{Zn}(\mathrm{II})$, and $\mathrm{Mn}(\mathrm{II})$ ) in Halobacterium sp. strain NRC-1 has been reported [22]. Besides studying the transcriptional 
TABLE 4: ABC transporters with various functions present in some model haloarchaea. $\mathrm{ABC}$ transporters have three components that together help in uptake of nutrients or for the efflux of extracellular proteins, enzymes, and toxicants. Permease is the transmembrane component and is responsible for the uptake of ions or macromolecules, while the ATP-binding component is the water soluble domain that binds ATP. Substrate binding at the substrate binding site brings about a conformational change in the ATP-binding component resulting in ATP hydrolysis. The presence or absence of the three components of $\mathrm{ABC}$ transporters for sugar, peptide, amino acids, phosphate, and iron transport is shown in the following table $[135,136]$.

\begin{tabular}{|c|c|c|c|c|c|c|c|}
\hline $\mathrm{ABC}$ transporters & H.s. & H.v. & H.m. & H.w. & H.l. & N.p. & N.m. \\
\hline \multicolumn{8}{|c|}{ Sugar transport system components } \\
\hline Permease & + & + & + & + & - & - & - \\
\hline ATP binding & + & + & + & + & - & - & - \\
\hline Substrate binding & - & - & + & + & + & - & - \\
\hline \multicolumn{8}{|c|}{ Phosphate transport system components } \\
\hline Permease & + & + & + & + & + & + & + \\
\hline ATP binding & - & + & + & + & + & + & + \\
\hline Susbtrate binding & + & + & + & + & + & + & + \\
\hline \multicolumn{8}{|c|}{ Dipeptide/oligopeptide transport system components } \\
\hline Permease & + & + & + & + & - & + & - \\
\hline ATP binding & + & + & + & + & + & + & + \\
\hline Susbtrate binding & - & - & + & + & - & + & + \\
\hline \multicolumn{8}{|c|}{ Amino acid transport system components } \\
\hline Permease & - & + & + & + & - & + & - \\
\hline ATP binding & + & + & + & + & - & + & - \\
\hline Susbtrate binding & - & + & - & + & + & + & + \\
\hline \multicolumn{8}{|c|}{$\mathrm{Fe}(\mathrm{III})$ transport system components } \\
\hline Permease & + & + & + & + & - & + & + \\
\hline ATP binding & + & + & - & - & - & + & - \\
\hline Susbtrate binding & - & - & - & + & + & + & - \\
\hline
\end{tabular}

H.s., Halobacterium sp. strain NRC-1; H.v., Haloferax volcanii; H.m., Haloarcula marismortui; H.w. Haloquadratum walsbyi; H.l., Halorubrum lacusprofundi; N.p, Natronomonas pharaonis; Natrialba magadii; (+) present; (-) absent.

changes by microarray analysis and mutant constructions, Kaur et al. (2006) [22] elucidated a systemic overview to metal stress response, thus providing a snapshot of various mechanisms involved in stress management. A total of 623 genes were found to be differentially regulated in presence of any of the six transition metals used for the study. Around $69 \%$ of these genes were early response genes; that is, they exhibited deviation from normal transcript levels within $0-$ 25 minutes of metal exposure. However, 91\% of these early response genes transcript levels reverted to preperturbation levels within 25-40 minutes. These included transcriptional regulator genes, transporter genes for phosphate, metals, and peptides, ribosomal protein genes, and protein export genes. Therefore, once the various damaged transcripts and proteins were replaced with the new proteins for managing metal stress and acclimatizing the cells to the new environment, the early response genes were found to revert to preperturbation levels [22].

One of the major toxic effects elicited by heavy metals is the rapid generation of reactive oxygen species (ROS) that damages the cellular machinery $[136,163]$. The ROS are usually scavenged by specific enzymatic detoxification systems like superoxide dismutases (SOD), peroxidases, dehydrogenases, and antioxidants like glutathione (GSH) [164]. Therefore, it follows that the genes involved in oxidative stress management are differentially regulated early in the stress management. Model haloarchaeal genomes, including Halobacterium salinarum and Haloferax volcanii, have been annotated with SOD [165] and catalase-peroxidase (KatG) genes [166]. Metal-induced ROS results in an early increase in the levels of transcripts of genes related to oxidative stress management like dehydrogenases and peroxidases in Halobacterium sp. strain NRC-1 [22].

Few of the early response genes found to be differentially regulated were transcriptional regulators like $t f b B$ and $\operatorname{Sir} R$. $\mathrm{TfbB}$ is the transcription initiation factor IIB. Its upregulation indicates a global response towards stress by increasing the rate of transcription to increase protein turnover. Similarly, the upregulation of SirR (silent information regulator) repressed the active uptake of $\mathrm{Mn}(\mathrm{II})$, thus providing the organism the ability to overcome the stress. Similar upregulation has also been observed in certain bacteria and yeast [167, 168]. Staphylococcus aureus and Staphylococcus epidermidis were shown to carry several copies of sirR genes that act as divalent metal cation-dependent transcriptional repressor [169]. cbiN, cbiM, and cbiQ involved in cobalt transport and 


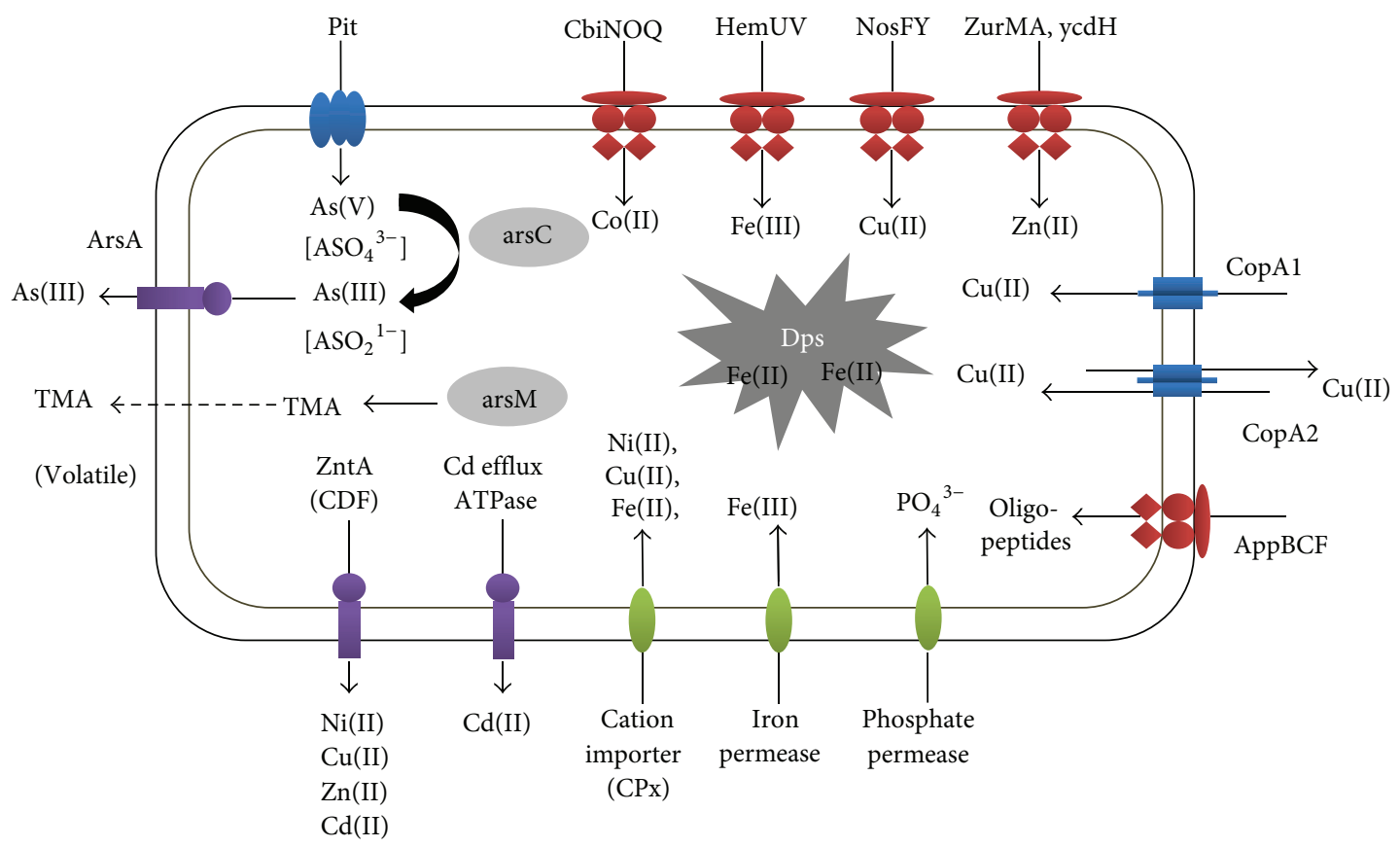

FIGURE 3: Various transporters playing a role in metal transport, homeostasis maintenance, and resistance in Halobacterium sp. strain NRC-1, reported to date. The efflux pumps of ATPases and $\mathrm{CDF}$ family involved in $\mathrm{Cd}, \mathrm{Ni}, \mathrm{Cu}, \mathrm{Zn}, \mathrm{Cd}$, and arsenite transport are represented in purple. $\mathrm{ABC}$ transporters (represented in red) involved in metal uptake are many. Certain toxic metals that do not have a dedicated uptake system may gain entry into the cell through other $\mathrm{ABC}$ transporters like oligopeptide and phosphate transporters. For example, the arsenate oxyanion gains entry into the cell through the pit/pst phosphate transporters due to its structural similarity to phosphate. The metal ions upon uptake can be detoxified either by enzymatic detoxification (ArsC and ArsM) or by chelation by peptides like Dps (DNA-binding protein of nutrient starved cells).

$z u r M, z u r A$, and $y c d H$ that encode $\mathrm{Mn} / \mathrm{Fe} \mathrm{ABC}$-transporters were predicted to be putatively regulated by sirR in Halobacterium sp. strain NRC-1 [170]. This was found to be consistent with the observation that $\operatorname{sir} R$ is essential for survival during metal-induced stress. This was evident from the upregulation of $\mathrm{Mn}(\mathrm{II})$ uptake genes $z u r M, z u r A$, and $y c d H$ in $\Delta \operatorname{sirR}$ strain as compared to parent strain in Halobacterium sp. strain NRC-1. Thus, in the haloarchaeon Halobacterium sp. strain NRC-1, sirR acts as a Mn(II)-dependent autorepressor [22].

A putative Lrp (leucine-responsive regulatory protein) family protein VNG1197C was reported to upregulate the $\mathrm{Cu}(\mathrm{II})-\mathrm{P}_{1 \mathrm{~B}}$ type ATPases gene $y v g X$ in Halobacterium sp. strain NRC-1 [22]. VNG1197C was found to be a Cu(II)dependent transcriptional activator carrying a metal-binding TRASH (trafficking, resistance, and sensing of heavy metals) domain. Kaur et al. (2006) [22] proposed that putative metallochaperones VNG0702H and/or VNG2581H deliver $\mathrm{Cu}(\mathrm{II}) / \mathrm{Zn}(\mathrm{II})$ to the TRASH domain of VNG1197C. This binding activates the transcription of $y v g X$ as well as the metallochaperones, thus providing $\mathrm{Cu}(\mathrm{II})$ resistance to Halobacterium sp. strain NRC-1. A similar pattern involving a metallochaperone (CopM), a transcriptional regulator with C-terminal TRASH domain (CopT), and a P-type $\mathrm{Cu}$ (II) exporting ATPase (CopA) forming the cop gene cluster for $\mathrm{Cu}$ (II) resistance has been described in Sulfolobus solfataricus, a thermoacidophilic crenarchaeon $[113,114]$.
Thus, organisms have the ability to differentiate between metal ions and therefore elicit responses that enable better survival. These responses could be local or global but in effect would be to efficiently handle the stress. The transcriptional regulation exhibited by Halobacterium sp. strain NRC-1 is an example of how metal homeostasis is maintained. Transient changes in transcripts to resist metals may play a major role in haloarchaea.

\section{Conclusion}

Haloarchaea encounter metals in their natural environment and utilize some of these metals for various key physiological functions. However, at higher concentrations, these metals can be toxic, and thus haloarchaea exhibit metal resistance mechanisms. Knowledge about metal physiology in haloarchaea is cursory, and therefore global studies for gaining insights into the metabolic regulations in response to metal stress are required. Metal physiology studies in model haloarchaeon Halobacterium sp. strain NRC-1 show that they have the ability to elicit a tailor-made response to metal stress. Other genera of the halophilic Euryarchaeota have not yet been subjected to such detailed studies with regard to metal homeostasis and resistance. The development of standard molecular and genetic tools for haloarchaea may facilitate better understanding of the various components 
involved in metal resistance including detoxifying enzymes, metallochaperones, and metal chelators and transporters. While assessing metal resistance in haloarchaea, the metal speciation should be given importance, as the metal might be unavailable to the cell for uptake, thus giving a higher MIC value. Therefore, beside understanding the molecular mechanisms underlying the resistance to metals, metal speciation and bio-availability studies should be carried out to obtain a complete picture. Further, this could facilitate the use of haloarchaea for bioremediation of metal-polluted hypersaline environments.

\section{Acknowledgments}

The authors thank the Ministry of Earth Science (MoES and the Government of India for their funding of the project MoES/11-MRDF/1/38/P/10-PC-III.

\section{References}

[1] H. B. Gray and W. R. Ellis Jr., "Electron transfer," in Bioinorganic Chemistry, I. Bertini, H. B. Gray, S. J. Lippard, and J. S. Valentine, Eds., pp. 315-364, University Science Books, Mill Valley, Calif, USA, 2006.

[2] A. W. Bott, "Redox properties of electron transfer metalloproteins," Current Separations, vol. 18, no. 2, pp. 47-54, 1999.

[3] A. Messerschmidt, R. Huber, K. Wieghart, and T. Poulos, Handbook of Metalloproteins, vol. 1-3, Wiley, New York, NY, USA, 2005.

[4] H. B. Gray, E. I. Stiefel, J. S. Valentine, and I. Bertini, Biological Inorganic Chemistry: Structure and Reactivity, University Science Books, Herndon, Va, USA, 2007.

[5] M. R. Bruins, S. Kapil, and F. W. Oehme, "Microbial resistance to metals in the environment," Ecotoxicology and Environmental Safety, vol. 45, no. 3, pp. 198-207, 2000.

[6] D. H. Nies, "Microbial heavy-metal resistance," Applied Microbiology and Biotechnology, vol. 51, no. 6, pp. 730-750, 1999.

[7] M. Hanikenne, U. Krämer, V. Demoulin, and D. Baurain, "A comparative inventory of metal transporters in the green alga Chlamydomonas reinhardtii and the red alga Cyanidioschizon merolae," Plant Physiology, vol. 137, no. 2, pp. 428-446, 2005.

[8] Z. Ma, F. E. Jacobsen, and D. P. Giedroc, "Coordination chemistry of bacterial metal transport and sensing," Chemical Reviews, vol. 109, no. 10, pp. 4644-4681, 2009.

[9] A. Bolchi, R. Ruotolo, G. Marchini et al., "Genome-wide inventory of metal homeostasis-related gene products including a functional phytochelatin synthase in the hypogeous mycorrhizal fungus Tuber melanosporum," Fungal Genetics and Biology, vol. 48, no. 6, pp. 573-584, 2011.

[10] J. M. Coombs and T. Barkay, "New findings on evolution of metal homeostasis genes: evidence from comparative genome analysis of bacteria and archaea," Applied and Environmental Microbiology, vol. 71, no. 11, pp. 7083-7091, 2005.

[11] S. Bartolucci, P. Contursi, G. Fiorentin, D. Limauro, and E. Pedone, "Responding to toxic compounds: a genomic and functional overview of Archaea," Frontiers in Bioscience, vol. 18, pp. 165-189, 2013.

[12] A. Oren, "Taxonomy of the family Halobacteriaceae: a paradigm for changing concepts in prokaryote systematics," International Journal of Systematic and Evolutionary Microbiology, vol. 62, no. 2, pp. 263-271, 2012.
[13] B. Zafrilla, R. M. Martínez-Espinosa, M. A. Alonso, and M. J. Bonete, "Biodiversity of Archaea and floral of two inland saltern ecosystems in the Alto Vinalopó Valley, Spain," Saline Systems, vol. 6, no. 1, p. 10, 2010.

[14] C. Bochiwal, Adaptation of Low-Salt Tolerant Haloarchaea in Estuarine Environments, University of Essex, Essex, UK, 2009.

[15] E. R. Sholkovitz, "Flocculation of dissolved organic and inorganic matter during the mixing of river water and seawater," Geochimica et Cosmochimica Acta, vol. 40, no. 7, pp. 831-845, 1976.

[16] C. S. R. Kumar, M. M. Joseph, T. R. G. Kumar, K. R. Renjith, M. N. Manju, and N. Chandramohanakumar, "Spatial variability and contamination of heavy metals in the inter-tidal systems of a tropical environment," International Journal of Environmental Research, vol. 4, no. 4, pp. 691-700, 2010.

[17] F. Pereira, S. Kerkar, and K. P. Krishnan, "Bacterial response to dynamic metal concentrations in the surface sediments of a solar saltern (Goa, India)," Environmental Monitoring and Assessment, 2012.

[18] P. M. Chapman and F. Wang, "Assessing sediment contamination in estuaries," Environmental Toxicology and Chemistry, vol. 20, no. 1, pp. 3-22, 2001.

[19] H. H. Tabak, P. Lens, E. D. Van Hullebusch, and W. Dejonghe, "Developments in bioremediation of soils and sediments polluted with metals and radionuclides-1. Microbial processes and mechanisms affecting bioremediation of metal contamination and influencing metal toxicity and transport," Reviews in Environmental Science and Biotechnology, vol. 4, no. 3, pp. 115-156, 2005.

[20] S. M. Ross, "Retention, transformation and mobility of toxic metals in soils," in Toxic Metals in Soil-Plant Systems, S. M. Ross, Ed., pp. 63-152, John Wiley \& Sons, Chichester, UK, 1994.

[21] G. Wang, S. P. Kennedy, S. Fasiludeen, C. Rensing, and S. DasSarma, "Arsenic resistance in Halobacterium sp. strain NRC-1 examined by using an improved gene knockout system," Journal of Bacteriology, vol. 186, no. 10, pp. 3187-3194, 2004.

[22] A. Kaur, M. Pan, M. Meislin, M. T. Facciotti, R. El-Gewely, and N. S. Baliga, "A systems view of haloarchaeal strategies to withstand stress from transition metals," Genome Research, vol. 16, no. 7, pp. 841-854, 2006.

[23] E. Bini, "Archaeal transformation of metals in the environment," FEMS Microbiology Ecology, vol. 73, no. 1, pp. 1-16, 2010.

[24] S. N. Sehgal and N. E. Gibbons, "Effect of some metal ions on the growth of Halobacterium cutirubrum," Canadian Journal of Microbiology, vol. 6, pp. 165-169, 1960.

[25] J. J. Nieto, A. Ventosa, and F. Ruiz-Berraquero, "Susceptibility of halobacteria to heavy metals," Applied and Environmental Microbiology, vol. 53, no. 5, pp. 1199-1202, 1987.

[26] G. Popescu and L. Dumitru, "Biosorption of some heavy metals from media with high salt concentrations by halophilic archaea," Biotechnology and Biotechnology Equipment, vol. 23, no. 2, pp. 791-795, 2009.

[27] I. Worms, D. F. Simon, C. S. Hassler, and K. J. Wilkinson, "Bioavailability of trace metals to aquatic microorganisms: importance of chemical, biological and physical processes on biouptake," Biochimie, vol. 88, no. 11, pp. 1721-1731, 2006.

[28] R. H. Byrne, "Inorganic speciation of dissolved elements in seawater: the influence of $\mathrm{pH}$ on concentration ratios," Geochemical Transactions, vol. 3, pp. 11-16, 2002.

[29] S. J. Markich, P. L. Brown, G. E. Batley, S. C. Apte, and J. L. Stauber, "Incorporating metal speciation and bioavailability 
into water quality guidelines for protecting aquatic ecosystems," Australian Journal of Ecotoxicology, vol. 7, no. 2, pp. 109-122, 2001.

[30] P. G. C. Campbell, "Interactions between trace metals and aquatic organisms: a critique of the free-ion activity model," in Metal Speciation and Bioavailability in Aquatic Systems, A. Tessier and D. R. Turner, Eds., pp. 45-102, Wiley, Chichester, UK, 1995.

[31] S. DasSarma and P. Arora, "Halophiles," in Encyclopedia of Life Sciences, vol. 8, pp. 458-466, Nature Publishing Group, London, UK, 2002.

[32] F. Pereira, K. P. Krishnan, R. K. Sinha, and S. Kerkar, "Insights on metal-microbe interactions in Bacillus sp. and Chromohalobacter sp. from a solar saltern," Journal of Ecobiotechnology, vol. 4, no. 1, pp. 14-24, 2012.

[33] T. M. Florence, "Development of physico-chemical speciation procedures to investigate the toxicity of copper, lead, cadmium and zinc towards aquatic biota," Analytica Chimica Acta, vol. 141, pp. 73-94, 1982.

[34] E. Tipping, S. Lofts, and A. J. Lawlor, "Modelling the chemical speciation of trace metals in the surface waters of the Humber system," Science of the Total Environment, vol. 210-211, pp. 63-77, 1998.

[35] Han Bin Xue and L. Sigg, "Zinc speciation in lake waters and its determination by ligand exchange with EDTA and differential pulse anodic stripping voltammetry," Analytica Chimica Acta, vol. 284, no. 3, pp. 505-515, 1994.

[36] C. D. Zamuda, D. A. Wright, and R. A. Smucker, “The importance of dissolved organic compounds in the accumulation of copper by the American Oyster, Crassostrea virginica," Marine Environmental Research, vol. 16, no. 1, pp. 1-12, 1985.

[37] H. W. Nurnberg, "Investigation on heavy metal speciation in natural waters by voltammetric procedures," Fresenius' Zeitschrift für Analytische Chemie, vol. 316, no. 6, pp. 557-565, 1983.

[38] L. L. L'her Roux, S. L. Le Roux, and P. Appriou, "Behaviour and speciation of metallic species $\mathrm{Cu}, \mathrm{Cd}, \mathrm{Mn}$ and $\mathrm{Fe}$ during estuarine mixing," Marine Pollution Bulletin, vol. 36, no. 1, pp. 56-64, 1998.

[39] M. J. Scoullos and A. S. Pavlidou, "Speciation studies of trace metals in the gulf of Elefsis, Greece," Croatica Chemica Acta, vol. 70, no. 1, pp. 289-307, 1997.

[40] W. G. Sunda and P. A. Gillespie, "The response of a marine bacterium to cupric ion and its use to estimate cupric ion activity in seawater," Journal of Marine Research, vol. 37, pp. 761$772,1979$.

[41] D. R. Turner, "Speciation and cycling of arsenic, cadmium, lead and mercury in natural waters," in Lead, Mercury, Cadmium and Arsenic in the Environment, T. C. Hutchinson and K. M. Meema, Eds., pp. 175-186, John Wiley and Sons Ltd., New York, NY, USA, 1987.

[42] D. Peakall and J. Burger, "Methodologies for assessing exposure to metals: speciation, bioavailability of metals, and ecological host factors," Ecotoxicology and Environmental Safety, vol. 56, no. 1, pp. 110-121, 2003.

[43] A. Jensen and F. Bro-Rasmussen, "Environmental cadmium in Europe," Reviews of Environmental Contamination and Toxicology, vol. 125, pp. 101-181, 1992.

[44] S. Luoma, "Fate, bioavailability and toxicity of silver in estuarine environments," in Proceedings of the 2nd International Conference: Transport, Fate and Effects of Silver in the Environment,
A. Andren and T. Bober, Eds., pp. 11151-14155, University of Wisconsin Sea Grant Institute, Madison, Wis, USA, September 1994.

[45] S. Noegrohati, "Sorption-desorption characteristics of heavy metals and their availability from the sediment of Segara anakan estuary," Indonesian Journal of Chemistry, vol. 5, no. 3, pp. 236244, 2005.

[46] D. W. Engel, W. Sunda, and B. A. Fowler, "Factors affecting trace metal uptake and toxicity to estuarine organisms. I. Environmental parameters," in Biological Monitoring of Marine Pollutants, F. J. Vernberg, A. Calabrese, F. T. Thurberg, and W. B. Vernberg, Eds., Academic Press, New York, NY, USA, 1981.

[47] P. R. Paquin, V. Zoltay, R. P. Winfield et al., "Extension of the biotic ligand model of acute toxicity to a physiologically-based model of the survival time of rainbow trout (Oncorhynchus mykiss) exposed to silver," Comparative Biochemistry and Physiology C, vol. 133, no. 1-2, pp. 305-343, 2002.

[48] J. G. Sanders and G. R. Abbe, "The role of suspended sediments and phytoplankton in the partitioning and transport of silver in estuaries," Continental Shelf Research, vol. 7, no. 11-12, pp. 13571361, 1987.

[49] R. Blust, M. Baillieul, and W. Decleir, "Effect of total cadmium and organic complexing on the uptake of cadmium by the brine shrimp, Artemia franciscana," Marine Biology, vol. 123, no. 1, pp. 65-73, 1995.

[50] P. Satish Nair and W. E. Robinson, "Histidine-rich glycoprotein in the blood of the bivalve Mytilus edulis: role in cadmium speciation and cadmium transfer to the kidney," Aquatic Toxicology, vol. 52, no. 2, pp. 133-142, 2001.

[51] G. M. Gadd, "Interactions of fungi with toxic metals," New Phytologist, vol. 124, no. 1, pp. 25-60, 1993.

[52] D. Blaudez, C. Jacob, K. Turnau et al., "Differential responses of ectomycorrhizal fungi to heavy metals in vitro," Mycological Research, vol. 104, no. 11, pp. 1366-1371, 2000.

[53] S. Silver and L. T. Phung, "Heavy metals, bacterial resistance," in Encyclopedia of Microbiology, M. Schaechter, Ed., pp. 220-227, Elsevier, Oxford, UK, 2009.

[54] S. V. Avery, "Metal toxicity in yeasts and the role of oxidative stress," Advances in Applied Microbiology, vol. 49, pp. 111-142, 2001.

[55] C. Cobbett and P. Goldsbrough, "Phytochelatins and metallothioneins: roles in heavy metal detoxification and homeostasis," Annual Review of Plant Biology, vol. 53, pp. 159-182, 2002.

[56] G. M. Cherian and H. M. Chan, "Biological functions of metallothioneins- a review," in Metallothionein III: Biological Roles and Medical Implications, K. T. Suzuki, N. Imura, and M. Kimura, Eds., pp. 87-109, Birkhauser Verlag, Basel, The Switzerland, 1993.

[57] H. Wang, Q. Zhang, B. Cai et al., "Solution structure and dynamics of human metallothionein-3 (MT-3)," FEBS Letters, vol. 580, no. 3, pp. 795-800, 2006.

[58] H. Glaeser, A. Coblenz, R. Kruczek, I. Ruttke, A. EbertJung, and K. Wolf, "Glutathione metabolism and heavy metal detoxification in Schizosaccharomyces pombe. Isolation and characterization of glutathione-deficient, cadmium-sensitive mutants," Current Genetics, vol. 19, no. 3, pp. 207-213, 1991.

[59] W. E. Rauser, "Phytochelatins and related peptides. Structure, biosynthesis, and function," Plant Physiology, vol. 109, no. 4, pp. 1141-1149, 1995.

[60] J. B. Neilands, "Siderophores: structure and function of microbial iron transport compounds," Journal of Biological Chemistry, vol. 270, no. 45, pp. 26723-26726, 1995. 
[61] F. A. Cotton and G. Wilkinson, Advanced Inorganic Chemistry, John Wiley and sons, New York, NY, USA, 4th edition, 1980.

[62] I. J. Schalk, M. Hannauer, and A. Braud, "New roles for bacterial siderophores in metal transport and tolerance," Environmental Microbiology, vol. 13, no. 11, pp. 2844-2854, 2011.

[63] T. E. Letain and K. Postle, “TonB protein appears to transduce energy by shuttling between the cytoplasmic membrane and the outer membrane in Escherichia coli," Molecular Microbiology, vol. 24, no. 2, pp. 271-283, 1997.

[64] P. M. Harrison and P. Arosio, "The ferritins: molecular properties, iron storage function and cellular regulation," Biochimica et Biophysica Acta, vol. 1275, no. 3, pp. 161-203, 1996.

[65] R. A. Grant, D. J. Filman, S. E. Finkel, R. Kolter, and J. M. Hogle, "The crystal structure of Dps, a ferritin homolog that binds and protects DNA," Nature Structural Biology, vol. 5, no. 4, pp. 294303, 1998.

[66] S. Nair and S. E. Finkel, "Dps protects cells against multiple stresses during stationary phase," Journal of Bacteriology, vol. 186, no. 13, pp. 4192-4198, 2004.

[67] A. R. Sundquist and R. C. Fahey, "The function of $\gamma$ glutamylcysteine and bis- $\gamma$-glutamylcystine reductase in Halobacterium halobium," Journal of Biological Chemistry, vol. 264, no. 2, pp. 719-725, 1989.

[68] L. Malki, M. Yanku, I. Borovok, G. Cohen, M. Mevarech, and Y. Aharonowitz, "Identification and characterization of gshA, a gene encoding the glutamate-cysteine ligase in the halophilic archaeon Haloferax volcanii," Journal of Bacteriology, vol. 191, no. 16, pp. 5196-5204, 2009.

[69] R. C. Fahey, "Novel thiols of prokaryotes," Annual Review of Microbiology, vol. 55, pp. 333-356, 2001.

[70] Y. Tanaka, K. Tsumoto, T. Nakanishi et al., "Structural implications for heavy metal-induced reversible assembly and aggregation of a protein: the case of Pyrococcus horikoshii CutA," FEBS Letters, vol. 556, no. 1-3, pp. 167-174, 2004.

[71] S. Reindel, S. Anemüller, A. Sawaryn, and B. F. Matzanke, "The DpsA-homologue of the archaeon Halobacterium salinarum is a ferritin," Biochimica et Biophysica Acta, vol. 1598, no. 1-2, pp. 140-146, 2002.

[72] S. Reindel, C. L. Schmidt, S. Anemüller, and B. F. Matzanke, "Expression and regulation pattern of ferritin-like DpsA in the Archaeon Halobacterium salinarum," BioMetals, vol. 18, no. 4, pp. 387-397, 2005.

[73] S. Bereswill, S. Greiner, A. H. M. Van Vliet et al., "Regulation of ferritin-mediated cytoplasmic iron storage by the ferric uptake regulator homolog (Fur) of Helicobacter pylori," Journal of Bacteriology, vol. 182, no. 21, pp. 5948-5953, 2000.

[74] B. P. Dave, K. Anshuman, and P. Hajela, "Siderophores of halophilic archaea and their chemical characterization," Indian Journal of Experimental Biology, vol. 44, no. 4, pp. 340-344, 2006.

[75] J. J. Harrison, R. J. Turner, and H. Ceri, "Metal tolerance in bacterial biofilms," Recent Research Developments in Microbiology, vol. 9, no. 1, pp. 33-55, 2009.

[76] G. M. Gadd, "Metals, minerals and microbes: geomicrobiology and bioremediation," Microbiology, vol. 156, no. 3, pp. 609-643, 2010.

[77] R. M. Donlan and J. W. Costerton, "Biofilms: survival mechanisms of clinically relevant microorganisms," Clinical Microbiology Reviews, vol. 15, no. 2, pp. 167-193, 2002.

[78] A. Poli, P. Di Donato, G. R. Abbamondi, and B. Nicolaus, "Synthesis, production, and biotechnological applications of exopolysaccharides and polyhydroxyalkanoates by archaea," Archaea, vol. 2011, Article ID 693253, 13 pages, 2011.

[79] Y. Kawakami, N. Hayashi, M. Ema, and M. Nakayama, "Effects of divalent cations on Halobacterium salinarum cell aggregation," Journal of Bioscience and Bioengineering, vol. 104, no. 1, pp. 42-46, 2007.

[80] H. Bolhuis, P. Palm, A. Wende et al., "The genome of the square archaeon Haloquadratum walsbyi: life at the limits of water activity," BMC Genomics, vol. 7, p. 169, 2006.

[81] N. S. Baliga, R. Bonneau, M. T. Facciotti et al., "Genome sequence of Haloarcula marismortui: a halophilic archaeon from the dead sea," Genome Research, vol. 14, no. 11, pp. 22212234, 2004.

[82] http://archaea.ucsc.edu/lists/haloTurk1/refSeq-list.html .

[83] W. V. Ng, S. P. Kennedy, G. G. Mahairas et al., "Genome sequence of Halobacterium species NRC-1," Proceedings of the National Academy of Sciences of the United States of America, vol. 97, no. 22, pp. 12176-12181, 2000.

[84] K. Kierek and P. I. Watnick, "The Vibrio cholerae O139 Oantigen polysaccharide is essential for $\mathrm{Ca} 2+$-dependent biofilm development in sea water," Proceedings of the National Academy of Sciences of the United States of America, vol. 100, no. 2, pp. 14357-14362, 2003.

[85] E. Banin, K. M. Brady, and E. P. Greenberg, "Chelator-induced dispersal and killing of Pseudomonas aeruginosa cells in a biofilm," Applied and Environmental Microbiology, vol. 72, no. 3, pp. 2064-2069, 2006.

[86] Y. Kawakami, T. Ito, M. Kamekura, and M. Nakayama, “Ca2+dependent cell aggregation of halophilic archaeon, Halobacterium salinarum," Journal of Bioscience and Bioengineering, vol. 100, no. 6, pp. 681-684, 2005.

[87] S. Frols, M. Dyall-Smith, and F. Pfeifer, "Biofilm formation by haloarchaea," Environmental Microbiology, vol. 14, no. 12, pp. 3159-3174, 2012.

[88] K. F. Jarrell, M. Stark, D. B. Nair, and J. P. J. Chong, "Flagella and pili are both necessary for efficient attachment of Methanococcus maripaludis to surfaces," FEMS Microbiology Letters, vol. 319, no. 1, pp. 44-50, 2011.

[89] D. J. Näther, R. Rachel, G. Wanner, and R. Wirth, "Flagella of Pyrococcus furiosus: multifunctional organelles, made for swimming, adhesion to various surfaces, and cell-cell contacts," Journal of Bacteriology, vol. 188, no. 19, pp. 6915-6923, 2006.

[90] B. Zolghadr, A. Kling, A. Koerdt, A. J. M. Driessen, R. Rachel, and S. V. Albers, "Appendage-mediated surface adherence of Sulfolobus solfataricus," Journal of Bacteriology, vol. 192, no. 1, pp. 104-110, 2010.

[91] S. V. Albers and M. Pohlschröder, "Diversity of archaeal type IV pilin-like structures," Extremophiles, vol. 13, no. 3, pp. 403-410, 2009.

[92] M. Tripepi, S. Imam, and M. Pohlschröder, "Haloferax volcanii flagella are required for motility but are not involved in PibDdependent surface adhesion," Journal of Bacteriology, vol. 192, no. 12, pp. 3093-3102, 2010.

[93] S. V. Albers, Z. Szabó, and A. J. M. Driessen, "Archaeal homolog of bacterial type IV prepilin signal peptidases with broad substrate specificity," Journal of Bacteriology, vol. 185, no. 13, pp. 3918-3925, 2003.

[94] S. Silver and L. T. Phung, "Bacterial heavy metal resistance: new surprises," Annual Review of Microbiology, vol. 50, pp. 753-789, 1996. 
[95] A. M. A. Nascimento and E. Chartone-Souza, "Operon mer: bacterial resistance to mercury and potential for bioremediation of contaminated environments," Genetics and Molecular Research, vol. 2, no. 1, pp. 92-101, 2003.

[96] A. Gupta, L. T. Phung, D. E. Taylor, and S. Silver, "Diversity of silver resistance genes in IncH incompatibility group plasmids," Microbiology, vol. 147, no. 12, pp. 3393-3402, 2001.

[97] R. Branco, A. P. Chung, and P. V. Morais, "Sequencing and expression of two arsenic resistance operons with different functions in the highly arsenic-resistant strain Ochrobactrum tritici SCII24T," BMC Microbiology, vol. 8, p. 95, 2008.

[98] S. Sri, L. S. M. Prashant, P. V. B. Chari, P. Rao, N. S. Balaravi, and P. V. K. Kishor, "Molecular identification of arsenic-resistant estuarine bacteria and characterization of their ars genotype," Ecotoxicology, vol. 21, no. 1, pp. 202-212, 2012.

[99] G. Endo and S. Silver, "CadC, the transcriptional regulatory protein of the cadmium resistance system of Staphylococcus aureus plasmid pI258," Journal of Bacteriology, vol. 177, no. 15, pp. 4437-4441, 1995.

[100] E. C. Teixeira, J. C. F. de Oliveira, M. T. M. Novo, and M. C. Bertolini, "The copper resistance operon copAB from Xanthomonas axonopodis pathovar citri: gene inactivation results in copper sensitivity," Microbiology, vol. 154, no. 2, pp. 402-412, 2008.

[101] S. Nawapan, N. Charoenlap, A. Charoenwuttitam, P. Saenkham, S. Mongkolsuk, and P. Vattanaviboon, "Functional and expression analyses of the cop operon, required for copper resistance in Agrobacterium tumefaciens," Journal of Bacteriology, vol. 191, no. 16, pp. 5159-5168, 2009.

[102] R. D. Stoppel and H. G. Schlegel, "Nickel-resistant bacteria from anthropogenically nickel-polluted and naturally nickelpercolated ecosystems," Applied and Environmental Microbiology, vol. 61, no. 6, pp. 2276-2285, 1995.

[103] T. V. Siunova, A. V. Siunov, V. V. Kochetkov, and A. M. Boronin, "The cnr-like operon in strain Comamonas sp. encoding resistance to cobalt and nickel," Russian Journal of Genetics, vol. 45, no. 3, pp. 292-297, 2009.

[104] B. Borremans, J. L. Hobman, A. Provoost, N. L. Brown, and D. Van Der Lelie, "Cloning and functional analysis of the pbr lead resistance determinant of Ralstonia metallidurans $\mathrm{CH} 34$," Journal of Bacteriology, vol. 183, no. 19, pp. 5651-5658, 2001.

[105] V. K. Singh, A. Xiong, T. R. Usgaard et al., "ZntR is an autoregulatory protein and negatively regulates the chromosomal zinc resistance operon znt of Staphylococcus aureus," Molecular Microbiology, vol. 33, no. 1, pp. 200-207, 1999.

[106] H. L. Ehrlich, "Microbes and metals," Applied Microbiology and Biotechnology, vol. 48, no. 6, pp. 687-692, 1997.

[107] M. Dopson, C. Baker-Austin, P. R. Koppineedi, and P. L. Bond, "Growth in sulfidic mineral environments: metal resistance mechanisms in acidophilic micro-organisms," Microbiology, vol. 149, no. 8, pp. 1959-1970, 2003.

[108] J. Schelert, V. Dixit, V. Hoang, J. Simbahan, M. Drozda, and P. Blum, "Occurrence and characterization of mercury resistance in the hyperthermophilic archaeon Sulfolobus solfataricus by use of gene disruption," Journal of Bacteriology, vol. 186, no. 2, pp. 427-437, 2004.

[109] J. Schelert, M. Drozda, V. Dixit, A. Dillman, and P. Blum, "Regulation of mercury resistance in the crenarchaeote Sulfolobus solfataricus," Journal of Bacteriology, vol. 188, no. 20, pp. 71417150, 2006.

[110] C. Baker-Austin, M. Dopson, M. Wexler et al., "Extreme arsenic resistance by the acidophilic archaeon Ferroplasma acidarmanus Ferl," Extremophiles, vol. 11, no. 3, pp. 425-434, 2007.

[111] A. Ruepp, W. Graml, M. L. Santos-Martinez et al., “The genome sequence of the thermoacidophilic scavenger Thermoplasma acidophilum," Nature, vol. 407, no. 6803, pp. 508-513, 2000.

[112] T. J. G. Ettema, A. B. Brinkman, P. P. Lamers, N. G. Kornet, W. M. de Vos, and J. van der Oost, "Molecular characterization of a conserved archaeal copper resistance (cop) gene cluster and its copper-responsive regulator in Sulfolobus solfataricus P2," Microbiology, vol. 152, no. 7, pp. 1969-1979, 2006.

[113] A. A. Villafane, Y. Voskoboynik, M. Cuebas, I. Ruhl, and E. Bini, "Response to excess copper in the hyperthermophile Sulfolobus solfataricus strain 98/2," Biochemical and Biophysical Research Communications, vol. 385, no. 1, pp. 67-71, 2009.

[114] A. Villafane, Y. Voskoboynik, I. Ruhl et al., "CopR of Sulfolobus solfataricusrepresents a novel class of archaeal-specific copperresponsive activators of transcription," Microbiology, vol. 157, no. 10, pp. 2808-2817, 2011.

[115] S. DasSarma, M. Capes, and P. DasSarma, "Haloarchaeal Megaplasmids," in Microbial Megaplasmids, E. Schwartz, Ed., pp. 3-30, Springer-Verlag, Berlin, Germany, 2009.

[116] W. V. Ng, S. A. Ciufo, T. M. Smith et al., "Snapshot of a large dynamic replicon in a halophilic archaeon: megaplasmid or minichromosome?" Genome Research, vol. 8, no. 11, pp. 11311141, 1998.

[117] R. Mukhopadhyay, B. P. Rosen, L. T. Phung, and S. Silver, "Microbial arsenic: from geocycles to genes and enzymes," FEMS Microbiology Reviews, vol. 26, no. 3, pp. 311-325, 2002.

[118] Y. Suzuki and H. Matsushita, "Interaction of metal ions and phospholipids monolayers as a biological membrane model," Industrial Health, vol. 6, no. 3, pp. 128-133, 1968.

[119] J. F. Stolz, P. Basu, and R. S. Oremland, "Microbial transformation of elements: the case of arsenic and selenium," International Microbiology, vol. 5, no. 4, pp. 201-207, 2002.

[120] S. Dey and B. P. Rosen, "Dual mode of energy coupling by the oxyanion-translocating ArsB protein," Journal of Bacteriology, vol. 177, no. 2, pp. 385-389, 1995.

[121] B. G. Butcher, S. M. Deane, and D. E. Rawlings, "The chromosomal arsenic resistance genes of Thiobacillus ferrooxidans have an unusual arrangement and confer increased arsenic and antimony resistance to Escherichia coli," Applied and Environmental Microbiology, vol. 66, no. 5, pp. 1826-1833, 2000.

[122] W. R. Cullen and R. Bentley, "The toxicity of trimethylarsine: an urban myth," Journal of Environmental Monitoring, vol. 7, no. 1, pp. 11-15, 2005.

[123] J. Qin, B. P. Rosen, Y. Zhang, G. Wang, S. Franke, and C. Rensing, "Arsenic detoxification and evolution of trimethylarsine gas by a microbial arsenite S-adenosylmethionine methyltransferase," Proceedings of the National Academy of Sciences of the United States of America, vol. 103, no. 7, pp. 2075-2080, 2006.

[124] C. Yuan, X. Lu, Q. Jie, B. P. Rosen, and X. C. Le, "Volatile arsenic species released from Escherichia coli expressing the aslll S-adenosylmethionine methyltransferase gene," Environmental Science and Technology, vol. 42, no. 9, pp. 3201-3206, 2008.

[125] A. M. Osborn, K. D. Bruce, P. Strike, and D. A. Ritchie, "Distribution, diversity and evolution of the bacterial mercury resistance (mer) operon," FEMS Microbiology Reviews, vol. 19, no. 4, pp. 239-262, 1997.

[126] T. P. Begley, A. E. Walts, and C. T. Walsh, "Mechanistic studies of a protonolytic organomercurial cleaving enzyme: bacterial organomercurial lyase," Biochemistry, vol. 25, no. 22, pp. 7192$7200,1986$. 
[127] http://archaea.ucsc.edu/lists/haloTurk1/refSeq-list.html .

[128] M. J. Fagan and M. H. Saier Jr., "P-type ATPases of eukaryotes and bacteria: sequence analyses and construction of phylogenetic trees," Journal of Molecular Evolution, vol. 38, no. 1, pp. 5799, 1994.

[129] M. Bublitz, J. Preben Morth, and P. Nissen, "P-type ATPases at a glance," Journal of Cell Science, vol. 124, no. 15, pp. 2515-2519, 2011.

[130] M. H. Saier Jr., "Computer-aided analyses of transport protein sequences: gleaning evidence concerning function, structure, biogenesis, and evolution," Microbiological Reviews, vol. 58, no. 1, pp. 71-93, 1994.

[131] M. D. Snavely, J. B. Florer, C. G. Miller, and M. E. Maguire, "Magnesium transport in Salmonella typhimurium: ${ }^{28} \mathrm{Mg}^{2+}$ transport by the CorA, MgtA, and MgtB systems," Journal of Bacteriology, vol. 171, no. 9, pp. 4761-4766, 1989.

[132] D. H. Nies, "Efflux-mediated heavy metal resistance in prokaryotes," FEMS Microbiology Reviews, vol. 27, no. 2-3, pp. 313-339, 2003.

[133] J. S. Klein and O. Lewinson, "Bacterial ATP-driven transporters of transition metals: physiological roles, mechanisms of action, and roles in bacterial virulence," Metallomics, vol. 3, no. 11, pp. 1098-1108, 2011.

[134] D. Raimunda, M. González-Guerrero, B. W. Leeber III, and J. M. Argüello, "The transport mechanism of bacterial $\mathrm{Cu}^{+}$-ATPases: distinct efflux rates adapted to different function," Biometals, vol. 24, no. 3, pp. 467-475, 2011.

[135] http://halo4.umbi.umd.edu/ .

[136] M. Valko, C. J. Rhodes, J. Moncol, M. Izakovic, and M. Mazur, "Free radicals, metals and antioxidants in oxidative stressinduced cancer," Chemico-Biological Interactions, vol. 160, no. 1, pp. 1-40, 2006.

[137] B. Fan and B. P. Rosen, "Biochemical characterization of CopA, the Escherichia coli $\mathrm{Cu}(\mathrm{I})$-translocating P-type ATPase," Journal of Biological Chemistry, vol. 277, no. 49, pp. 46987-46992, 2002.

[138] Franke S, G. Grass, and D. H. Nies, "The product of the ybdE gene of the Escherichia coli chromosome is involved in detoxification of silver ions," Microbiology, vol. 147, no. 4, pp. 965-972, 2001.

[139] L. Tong, S. Nakashima, M. Shibasaka, M. Katsuhara, and K. Kasamo, "A novel histidine-rich CPx-ATPase from the filamentous cyanobacterium Oscillatoria brevis related to multipleheavy-metal cotolerance," Journal of Bacteriology, vol. 184, no. 18, pp. 5027-5035, 2002.

[140] S. Tottey, P. R. Rich, S. A. M. Rondet, and N. J. Robinson, "Two menkes-type ATPases supply copper for photosynthesis in synechocystis PCC 6803," Journal of Biological Chemistry, vol. 276, no. 23, pp. 19999-20004, 2001.

[141] M. Solioz and J. V. Stoyanov, "Copper homeostasis in Enterococcus hirae," FEMS Microbiology Reviews, vol. 27, no. 2-3, pp. 183-195, 2003.

[142] I. T. Paulsen and M. H. Saier Jr., "A novel family of ubiquitous heavy metal ion transport proteins," Journal of Membrane Biology, vol. 156, no. 2, pp. 99-103, 1997.

[143] R. Sharma, C. Rensing, B. P. Rosen, and B. Mitra, “The ATP hydrolytic activity of purified $\mathrm{ZntA}$, a $\mathrm{Pb}(\mathrm{II}) / \mathrm{Cd}(\mathrm{II}) / \mathrm{Zn}(\mathrm{II})$ translocating ATPase from Escherichia coli," Journal of Biological Chemistry, vol. 275, no. 6, pp. 3873-3878, 2000.

[144] B. Montanini, D. Blaudez, S. Jeandroz, D. Sanders, and M. Chalot, "Phylogenetic and functional analysis of the Cation Diffusion Facilitator (CDF) family: improved signature and prediction of substrate specificity," BMC Genomics, vol. 8, p. 107, 2007.

[145] C. J. Haney, G. Grass, S. Franke, and C. Rensing, "New developments in the understanding of the cation diffusion facilitator family," Journal of Industrial Microbiology and Biotechnology, vol. 32, no. 6, pp. 215-226, 2005.

[146] A. Anton, C. Große, J. Reißmann, T. Pribyl, and D. H. Nies, "CzcD is a heavy metal ion transporter involved in regulation of heavy metal resistance in Ralstonia sp. strain CH34," Journal of Bacteriology, vol. 181, no. 22, pp. 6876-6881, 1999.

[147] Y. Wei and D. Fu, "Selective metal binding to a membraneembedded aspartate in the Escherichia coli metal transporter YiiP (FieF)," Journal of Biological Chemistry, vol. 280, no. 40, pp. 33716-33724, 2005.

[148] Z. Hou and B. Mitra, "The metal specificity and selectivity of ZntA from Escherichia coli using the acyl phosphate intermediate," Journal of Biological Chemistry, vol. 278, no. 31, pp. 2845528461, 2003.

[149] S. Stumpe and E. P. Bakker, "Requirement of a large K+-uptake capacity and of extracytoplasmic protease activity for protamine resistance of Escherichia coli," Archives of Microbiology, vol. 167, no. 2-3, pp. 126-136, 1997.

[150] J. R. H. Tame, G. N. Murshudov, E. J. Dodson et al., "The structural basis of sequence-independent peptide binding by OppA protein," Science, vol. 264, no. 5165, pp. 1578-1581, 1994.

[151] D. E. Salt and G. J. Wagner, "Cadmium transport across tonoplast of vesicles from oat roots. Evidence for a $\mathrm{Cd} 2+/ \mathrm{H}+$ antiport activity," Journal of Biological Chemistry, vol. 268, no. 17, pp. 12297-12302, 1993.

[152] P. A. Rea, Z. S. Li, Y. P. Lu, Y. M. Drozdowicz, and E. Martinoia, "From vacuolar GS-X pumps to multispecific ABC transporters," Annual Review of Plant Biology, vol. 49, pp. 727760, 1998.

[153] H. W. Van Veen, R. Callaghan, L. Soceneantu, A. Sardini, W. N. Konings, and C. F. Higgins, "A bacterial antibiotic-resistance gene that complements the human multidrug-resistance Pglycoprotein gene," Nature, vol. 391, no. 6664, pp. 291-295, 1998.

[154] H. W. Van Veen, A. Margolles, M. Müller, C. F. Higgins, and W. N. Konings, "The homodimeric ATP-binding cassette transporter LmrA mediates multidrug transport by an alternating two-site (two-cylinder engine) mechanism," EMBO Journal, vol. 19, no. 11, pp. 2503-2514, 2000.

[155] A. L. Hartman, C. Norais, J. H. Badger et al., "The complete genome sequence of Haloferax volcanii DS2, a model archaeon," PloS One, vol. 5, no. 3, p. e9605, 2010.

[156] M. Falb, F. Pfeiffer, P. Palm et al., "Living with two extremes: conclusions from the genome sequence of Natronomonas pharaonis," Genome Research, vol. 15, no. 10, pp. 1336-1343, 2005.

[157] J. R. Roth, J. G. Lawrence, M. Rubenfield, S. Kieffer-Higgins, and G. M. Church, "Characterization of the cobalamin (vitamin B12) biosynthetic genes of Salmonella typhimurium," Journal of Bacteriology, vol. 175, no. 11, pp. 3303-3316, 1993.

[158] J. D. Faraldo-Gómez and M. S. P. Sansom, "Acquisition of siderophores in gram-negative bacteria," Nature Reviews Molecular Cell Biology, vol. 4, no. 2, pp. 105-116, 2003.

[159] S. Schneider and M. Paoli, "Crystallization and preliminary Xray diffraction analysis of the haem-binding protein HemS from Yersinia enterocolitica," Acta Crystallographica Section F, vol. 61, no. 8, pp. 802-805, 2005. 
[160] W. G. Zumft, A. Viebrock-Sambale, and C. Braun, "Nitrous oxide reductase from denitrifying Pseudomonas stutzeri.Genes for copper-processing and properties of the deduced products, including a new member of the family of ATP/GTP-binding proteins," European Journal of Biochemistry, vol. 192, no. 3, pp. 591-599, 1990.

[161] B. Usadel, O. E. Bläsing, Y. Gibon et al., "Global transcript levels respond to small changes of the carbon status during progressive exhaustion of carbohydrates in arabidopsis rosettes," Plant Physiology, vol. 146, no. 4, pp. 1834-1861, 2008.

[162] D. Mittal, D. A. Madhyastha, and A. Grover, "Genome-wide transcriptional profiles during temperature and oxidative stress reveal coordinated expression patterns and overlapping regulons in rice," PLoS One, vol. 7, no. 7, Article ID e40899, 2012.

[163] N. Ercal, H. Gurer-Orhan, and N. Aykin-Burns, "Toxic metals and oxidative stress part I: mechanisms involved in metalinduced oxidative damage," Current topics in medicinal chemistry, vol. 1, no. 6, pp. 529-539, 2001.

[164] G. Storz and J. A. Imlay, "Oxidative stress," Current Opinion in Microbiology, vol. 2, no. 2, pp. 188-194, 1999.

[165] M. D. Capes, J. A. Coker, R. Gessler et al., "The information transfer system of halophilic archaea," Plasmid, vol. 65, no. 2, pp. 77-101, 2011.

[166] S. Siddaramappa, J. F. Challacombe, R. E. DeCastro et al., "A comparative genomics perspective on the genetic content of the alkaliphilic haloarchaeon Natrialba magadii ATCC, 43099," BMC Genomics, vol. 13, p. 165, 2012.

[167] Q. Que and J. D. Helmann, "Manganese homestasis in Bacillus subtilis is regulated by MntR, a bifunctional regulator related to the diphtheria toxin repressor family of proteins," Molecular Microbiology, vol. 35, no. 6, pp. 1454-1468, 2000.

[168] L. T. Jensen, M. Ajua-Alemanji, and V. C. Culotta, "The Saccharomyces cerevisiae high affinity phosphate transporter encoded by PHO84 also functions in manganese homeostasis," Journal of Biological Chemistry, vol. 278, no. 43, pp. 4203642040, 2003.

[169] P. J. Hill, A. Cockayne, P. Landers, J. A. Morrissey, C. M. Sims, and P. Williams, "SirR, a novel iron-dependent repressor in Staphylococcus epidermidis," Infection and Immunity, vol. 66, no. 9, pp. 4123-4129, 1998.

[170] R. Bonneau, D. J. Reiss, P. Shannon et al., "The inferelator: an algorithn for learning parsimonious regulatory networks from systems-biology data sets de novo," Genome Biology, vol. 7, no. 5, Article ID R36, 2006. 

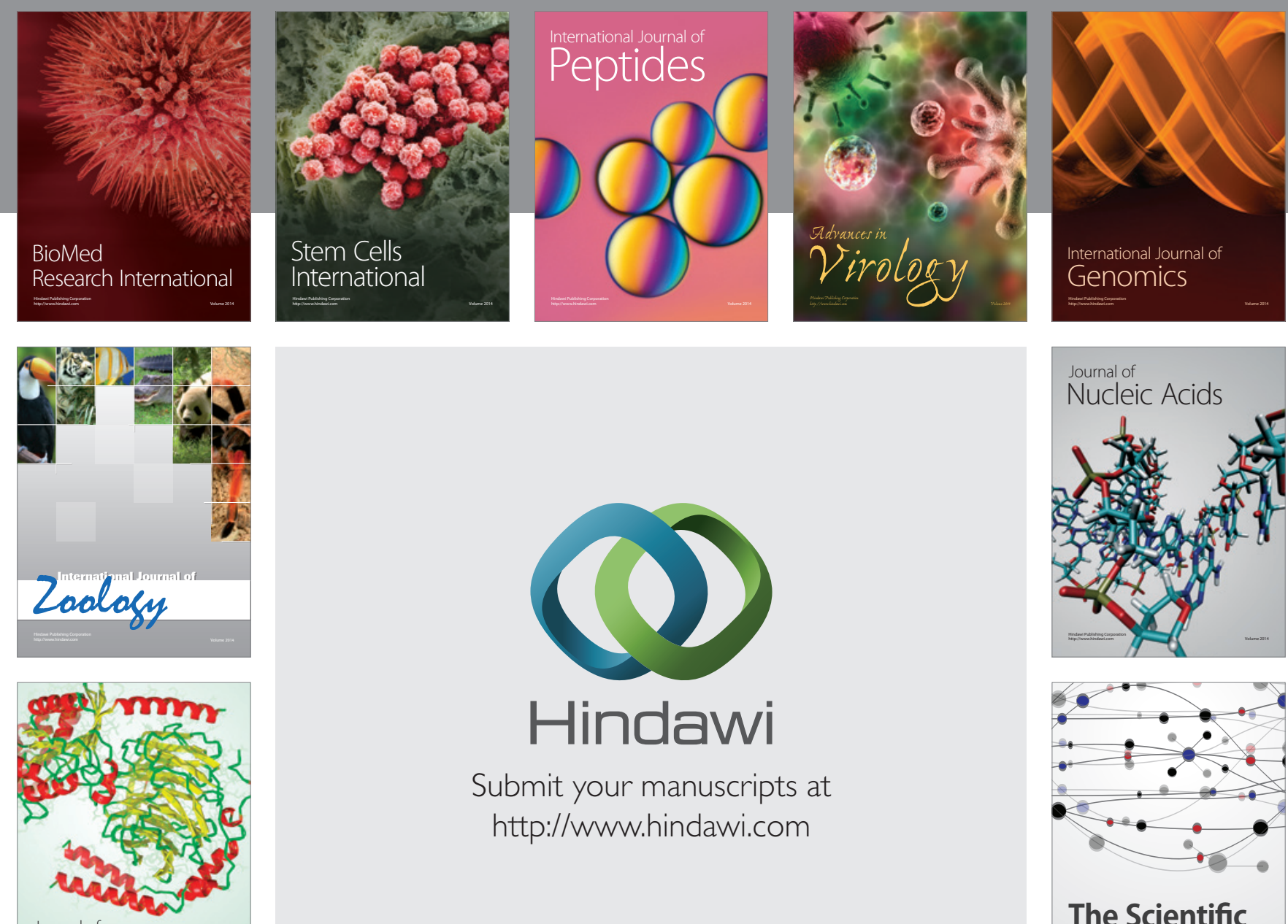

Submit your manuscripts at

http://www.hindawi.com

Journal of
Signal Transduction
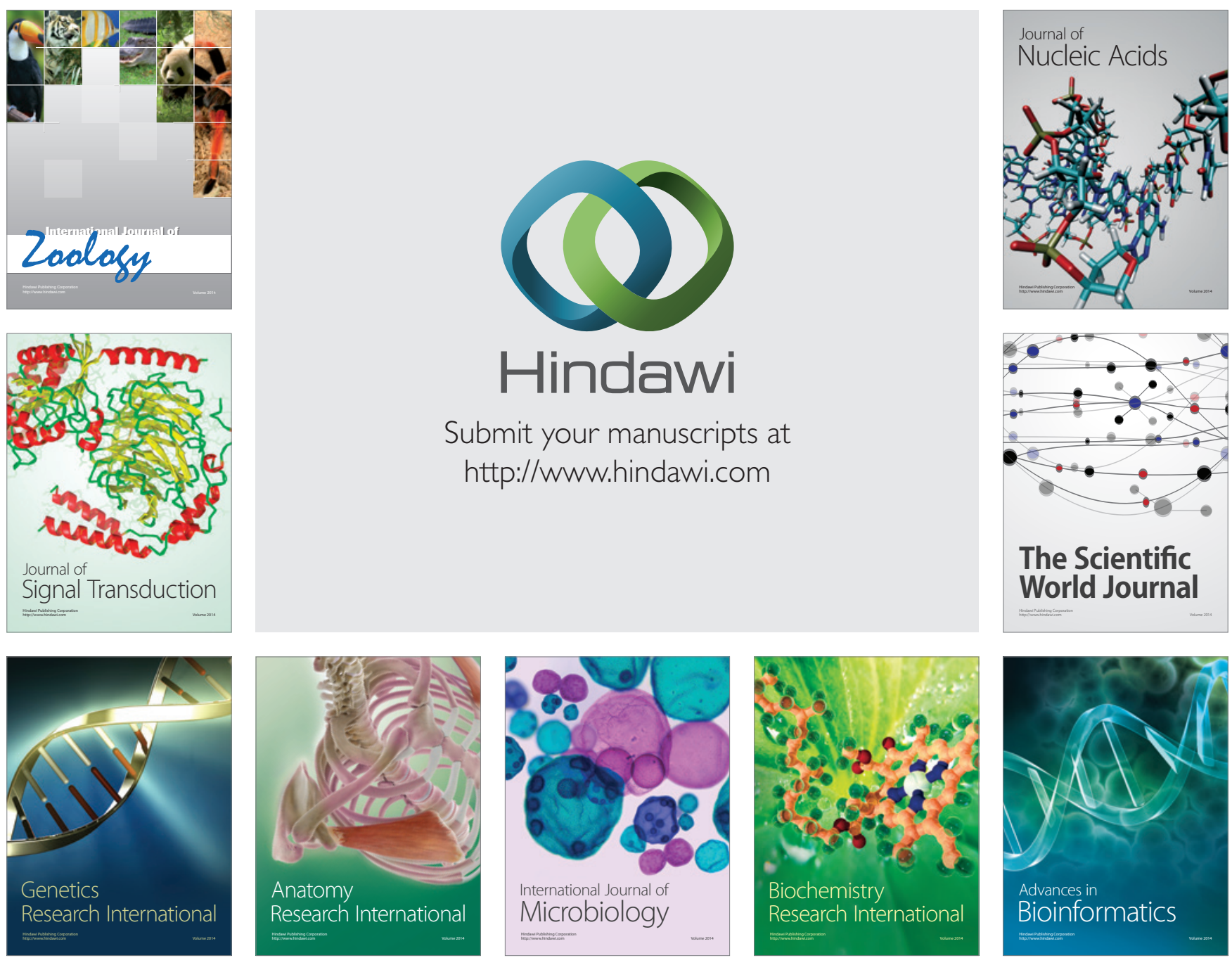

The Scientific World Journal
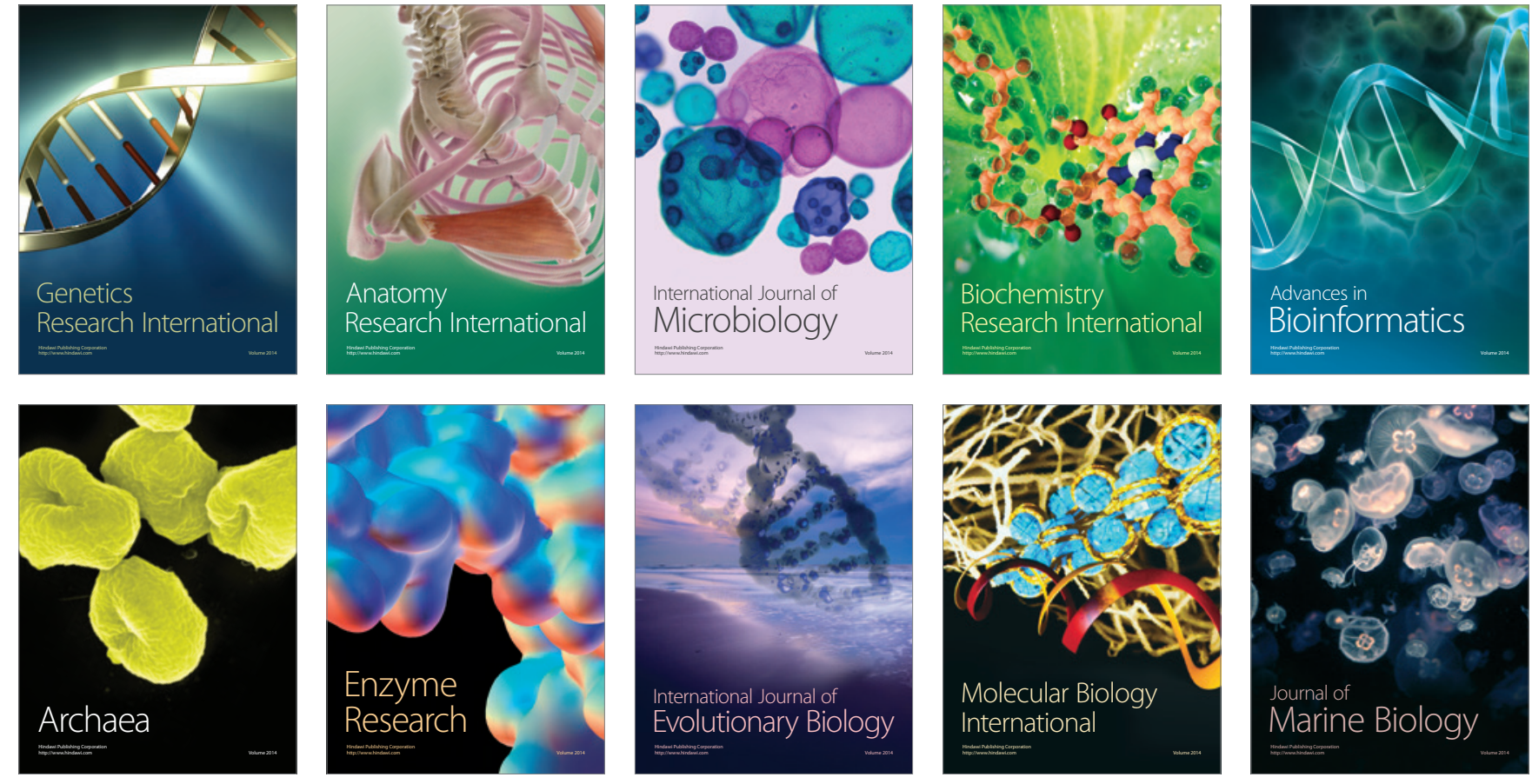